


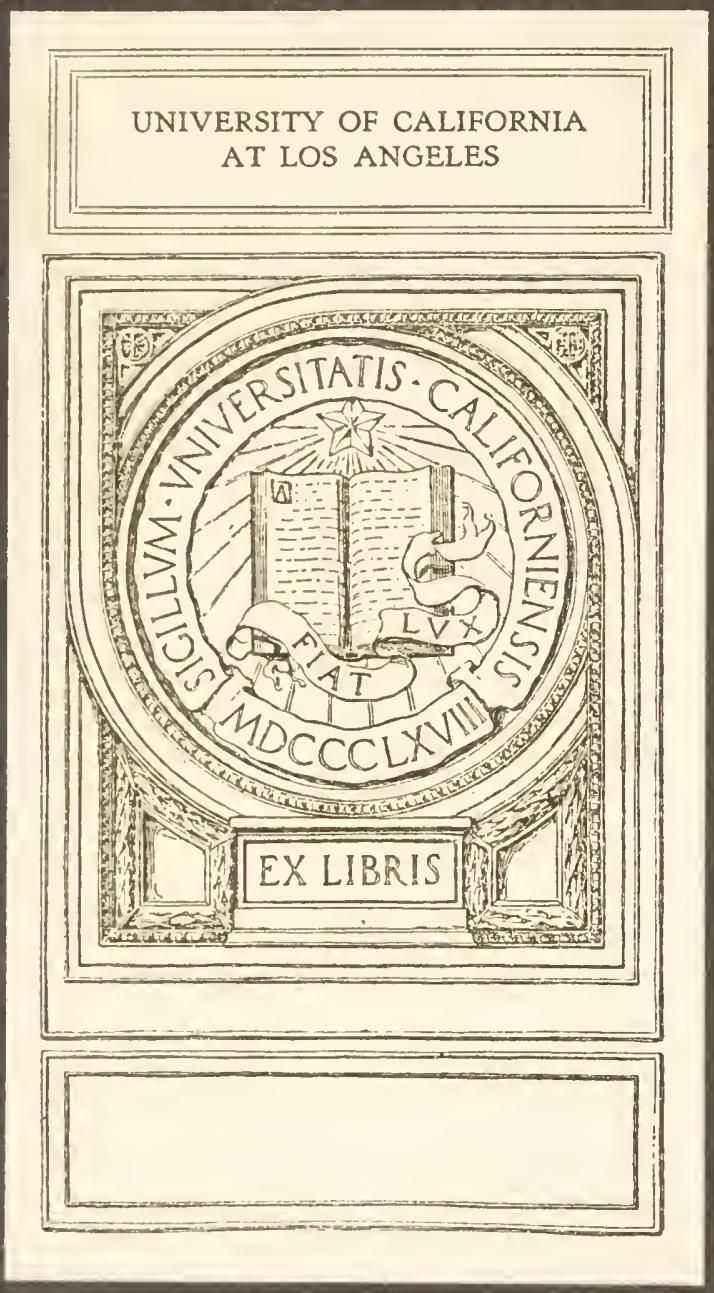




$$
\text { S.r. Me Buide }
$$

REPORT OF THE PSYCHOLOGY COMMITTEE OF THE NATIONAL RESEARCH COUNCIL

BY MAJOR ROBERT M. YERKES

Reprinted from The Psychological Review, Vol. 26, No. 2, March, igrg.] 

Ed./Psych.

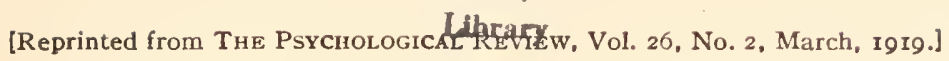

\section{REPORT OF THE PSYCHOLOGY COMMITTEE OF THE NATIONAL RESEARCH COUNCIL}

Respectfully submitted to Dr. George E. Hale, Chairman National Research Council BY MAJOR ROBERT M. YERKES,

Chairman of the Psychology Committee. ${ }^{1}$

\section{Organization of the Psychology Committee}

The Psychology Committee was organized in April, I9I7, at the request of the Chairman of the Research Council, because of the appearance of psychological military problems and the formulation of plans for participation in the war by the Council of the American Psychological Association. ${ }^{2}$

The constitution of the Committee, together with such changes as have occurred by reason of resignation or additional appointments, is indicated below: James R. Angell, ${ }^{3}$ J. McKeen Cattell, Raymond Dodge, Shepherd I. Franz, G. Stanley Hall, Walter Dill Scott, Carl E. Seashore, Edward L. Thorndike, John B. Watson, G. M. Whipple, Robert M. Yerkes, Chairman, and the late John W. Baird, Vice-chairman.

Simultaneously with the organizing of the Psychology Committee of the National Research Council, the Council of the American Psychological Association authorized the appointment and designated the chairmen of twelve committees of the Association to deal with various aspects of the rela-

${ }^{1}$ Grateful acknowledgment is made by the Chairman of the Committee to Captain Richard M. Elliott for his assistance in the preparation of this report.

${ }^{2}$ An account of the events which preceded the organizing of this committee and of its early activities was published under the title "Psychology in Relation to the War" in the Psychological Review, 25, 85-I15, March, I9I8.

${ }^{3}$ Angell and Scott were appointed in October, 1917. Cattell resigned in October, (1917. Baird was appointed Vice-chairman in March, 1918. 


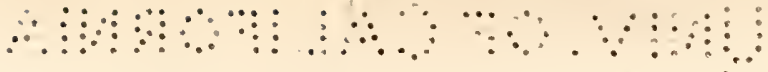

$\because \because \because \therefore \because \because \because \because:$

tions of psychology to the war. With a few exceptions, these committees were ultimately organized by their chairmen. Subsequently all which attained complete organization and became active were constituted subcommittees of the Psychology Committee of the Research Council. This was done for convenience and efficiency of administration, since the chairman of the Psychology Committee of the Research Council was also, during the year I918, President of the American Psychological Association and in this capacity responsible for the operation of the Association's war committees.

The following list of committees which have been active for varying periods during the military emergency at once supplements the history of psychological service previously published in this journal and supplies a scheme for the presentation of the results achieved by the Psychology Committee and through its coöperation.

I. Committee on psychological literature relating to military affairs. Chairman, Madison Bentley.

2. Committee on the psychological examination of recruits. Chairman, Robert M. Yerkes.

3. Committee on psychological problems of aviation, including examination of aviation recruits. Chairmen, Harold E. Burtt, George M. Stratton, and Edward L. Thorndike (serving successively).

4. Committee on the selection of men for tasks requiring special aptitude. Chairman, Edward L. Thorndike.

5. Committee on recreation in the army and navy. Chairman, George A. Coe.

6. Committee on problems of vision which have military significance. Chairman, Raymond Dodge.

7. Committec on pedagogical and psychological problems of military training and discipline. Chairmen, Charles $\mathrm{H}$. Judd and William C. Bagley (serving successively).

8. Committee on psychological problems of incapacity, including thosc of shcll-shock and reëducation. Chairman, Shepherd I. Franz.

9. Committee on problems of emotional stability, fear and self-control. Chairman, Robert S. Woodworth. 
10. Committee on "Propaganda behind the German Lines." Chairman, James R. Angell.

II. Committee on acoustic problems of military importance. Chairman, Carl E. Seashore.

I2. Committee on tests for deception. Chairman, John F. Shepard.

13. Committee on adaptation of psychological instruction to military educational needs. Chairman, Raymond Dodge.

In addition to the lines of service indicated by the titles of committees, special work was done by individual members of the Psychology Committee or of its subcommittees as follows:

I4. For the Division of Military Intelligence, on methods of selecting and training scouts and observers, by John B. Watson and Madison Bentley.

I5. For the Chemical Warfare Service, on psychological problems of the gas mask, by Raymond Dodge, John W. Baird, and Knight Dunlap.

16. For the Committee on Education and Special Training of the War Department, on adaptation of army intelligence tests for use in the Students' Army Training Corps, by Lewis M. Terman.

17. For various military and civilian agencies, studies of special problems in learning, methods of instruction, and methods of selecting for special tasks, by L. L. Thurstone, Herbert S. Langfeld, and Robert S. Woodworth.

\section{Committee Service and Expenditures}

The Psychology Committee depended chiefly on three instrumentalities for the conduct of its service and research: subcommittees, conferences, and appointments in the army or navy. The results obtained through these several instrumentalities will be presented under the subcommittees or special topics listed above.

Though many of the subcommittees have seemingly played unimportant rôles, it is nevertheless clear that this form of organization was indispensable for the instigation and main- 
tenance of service. Appointments in the army and navy rank next in importance, for it usually was found desirable to have experienced and highly trained specialists administer for the army or navy the methods which were prepared and recommended by the Committee or its subcommittees. The conference has served the important purpose of bringing together, for a relatively short period, a group of individuals especially interested in and competent to discuss and advise concerning certain immediately important practical questions.

Although the activities of the Psychology Committee have extended over a period of nearly two years, its expenditures, omitting clerical help, office rental, and supplies which were furnished by the Research Council, amount to less than twenty-five hundred dollars. Of this sum approximately nine hundred dollars was used for the personal assistance of psychologists in the work of the Committee or of the Division of Psychology, Surgeon General's Office; about one thousand dollars for conference expenses, and the remainder for printing, preparation of charts, and incidentals.

\section{Organization and Services of Subcommittees} and Special Investigations of the Psychology CommitTEE

I. Committee on Psychological Literature Relating to Military Affairs.-This committee was originally authorized by the Council of the American Psychological Association, which at the same time designated Howard C. Warren as chairman. Because of Warren's inability to serve, Madison Bentley was made chairman of the committee. Bentley, although never assisted by an organized group, rendered important service by supplying the various committees and subcommittees with references to pertinent psychological articles and with summaries of the more important of such articles.

This work ceased when Bentley accepted appointment in the Signal Corps to assist with the work of the Aviation Examining Boards.

He had already succeeded in demonstrating to the satisfaction of psychologists who were directing the activities of 
subcommittees that the psychological literature relating to military problems was not of great practical importance in connection with the emergency, because most of the tasks presented to or discovered by the committee demanded engineering of the pioneer sort.

2. Committee on the Psychological Examination of Recruits. - This committee of the Psychological Association was accepted as a subcommittee of the Psychology Committee of the Research Council in November, I9I7. It was organized in May, I9I7, with the following membership: Walter V. Bingham, Herbert H. Goddard, Thomas H. Haines, Lewis M. Terman, F. Lyman Wells, Guy M. Whipple, and Robert M. Yerkes, chairman. ${ }^{1}$

During June, July, and August of 1917, the committee prepared and directed the trial of group and individual procedures for psychological examination of recruits. Subsequently, various members of the committee ${ }^{2}$ made indispensable contributions by assisting with the revision of the methods.

The final meeting of this committee was held on June $\mathbf{1 7}$, 19I8, on which date it was called in conference by the chairman of the Psychology Committee of the Research Council to consider the scientific utilization of methods and results of mental testing in the army. At this conference, it was decided to attempt to preserve for subsequent careful analysis and statistical study at least 200,000 of the original records of psychological examinations of recruits. At the same time, the committee carefully considered and formulated for the guidance of the Division of Psychology, Medical Department of the Army, advice concerning the revision and utilization of methods of examining.

The methods prepared for the army by this committee, consisting of a procedure for the examination of large groups of subjects and also a series of tests for individual examination, were accepted by the Medical Department of the Army

${ }_{1}^{1}$ The committee was assisted in its early work on methods by N. J. Melville, E. A. Doll, and members of the Department of Psychological Research of the School for the Feeble-minded, Vineland, N. J.

2 Notably, Bingham, Haines, Terman, and Whipple. 
in August, 1917, for official trial. They have since been thoroughly revised and importantly supplemented in the light of extensive results.

During November and December of 1917 thorough military trial of these methods in four cantonments yielded results which led the Surgeon General to recommend to the War Department the extension of psychological examining to include "all company officers, all candidates for officers' training camps, and all drafted and enlisted men."

This extension was approved by the War Department in January, I9I8, and at the same time a Division of Psychology was created in the Office of the Surgeon General to organize and direct this new variety of service.

To supply the requisite trained personnel for psychological examining, a school of Military Psychology was established at the Medical Officers' Training Camp, Fort Oglethorpe, Georgia. Approximately one hundred officers and three hundred enlisted men were given two months of intensive training in this school. The instruction included, in addition to training in procedures of army psychological examining, the courses in military drill, army paper work, and medical department administration, regularly required for medical officers of the army.

The methods were carefully revised during January and February, 19I8, as a result of the official trial; the necessary equipment to supply approximately two hundred examining officers was manufactured, and the various forms of examination blank were printed in large editions in order that all examining stations should be adequately equipped.

Suitable buildings for psychological work were either assigned or constructed in the principal army training camps, and within a few months the service was satisfactorily organized.

The principal results of psychological examining may be summarized statistically and their applications briefly indicated.

The work of mental examining was organized finally in thirty-five army training camps. A grand total of $1,726,000$ 
men had been given psychological examination prior to January I, I9I9. Of this number, about 4I,000 were commissioned officers. More than 83,000 of the enlisted men included in the total had been given an individual examination in addition to the group examination for literates, for illiterates, or both.

Between April 27 and November 30, I9I8, 7,749 (0.5 per cent.) were reported for discharge by psychological examiners because of mental inferiority. The number of recommendations for assignment to labor battalions because of low-grade intelligence was 9,87 I (o.6+ per cent.). A total of 9,432 men $(0.6+$ per cent.) were recommended for assignment to development battalions in order that they might be carefully observed and given preliminary training to discover, if possible, ways of using them in the army.

During this same period of six months, there were reported 4,744 men with mental age ratings below seven years; 7,762 between seven and eight years; 14,566 between eight and nine years; $18,58 \mathrm{I}$ between nine and ten years. This gives a total of 45,653 ( 3 per cent.) men under ten years' mental age. It is extremely improbable that many of these individuals were worth what it cost the government to maintain, equip, and train them for military service.

The original purpose of psychological examining in the army was stated as follows in the preamble to the plan first submitted to the Surgeon General: "The Council of the American Psychological Association is convinced that in the present emergency American psychology can substantially serve the government, under the Medical Corps of the Army and Navy, by examining recruits with respect especially to intellectual deficiency, psychopathic tendencies, nervous instability, and inadequate self-control."

It was the expectation of psychological examiners that their principal service would be assistance in the prompt discovery and proper disposition of mental defectives. Long before the official trial of methods of examining had ended, however, it had become clear that various other applications were desired by officers of the line and that the significance of 
psychological service would unquestionably be much broader than had been supposed. The official medical inspector of this work in his report listed its chief purposes as: (a) to aid in segregating the mentally incompetent, $(b)$ to classify men according to their mental capacity, and (c) to assist in selecting competent men for responsible positions.

With the extension of psychological examining, these three lines of application rapidly became differentiated, and both line and medical officers discovered, for themselves or with the assistance of psychological examiners, new and important ways of utilizing mental ratings to increase military efficiency and to lessen the cost of training and maintenance. The principal practical uses of these ratings common to the majority of the training camps in which the service was organized are listed below:

(I) For the discovery of men whose superior intelligence warranted their consideration for promotion, special training or assignment to positions of unusual responsibility or difficulty; (2) for assistance in selecting suitable candidates for officers' training schools, non-commissioned officers' training schools and other special training organizations; (3) for the guidance of personnel adjutants in the assignment of recruits so that organizations might be built in accordance with desirable intelligence specifications or, in the absence of such specifications, so that their different constituent parts, such for example as the companies of a regiment, should possess approximately the same mental strength, thus avoiding the risk of weak links in the army chain; (4) for the prompt discovery of men whose low grade intelligence or mental peculiarities rendered them of uncertain value in the army, and the assignment of such individuals to development battalions for observation and preliminary training; (5) for the discovery and recommendation or assignment to labor battalions of men obviously so inferior mentally as to be unsuitable for regular military training, yet promising serviceableness in simple manual labor; (6) for the discovery of men whose mental inferiority unfitted them for any sort of military duty and whose rejection or discharge should therefore be recommended 
to medical officers; (7) for utilization in connection with the organization of special training groups so that each group might be instructed or drilled in accordance with its mental capacity, thus avoiding the delay incident to dull or awkward individuals and enabling the especially able men to proceed rapidly and ultimately to take special forms of training in preparation for promotion or other forms of responsibility.

The judgment of the army concerning the practical value of this work has been very clearly indicated by reports of commanding officers. On completion of the official trial of methods in four cantonments, approximately seventy-five per cent. of the regimental and company commanders who were more or less familiar with the psychological ratings and their proposed applications expressed their approval of this new line of service and the opinion that it should be continued, extended, and its military usefulness increased. As the organization of the service was gradually perfected and the officers of the line and the Medical Corps became acquainted with its actual and possible values to them, the proportion of favorable opinion tended to increase.

The psychological service was so organized in each large training camp that a staff of four officers of the Sanitary Corps, six enlisted men, also trained in military psychology, and thirty to forty privates temporarily assigned for service as scorers, clerks, and orderlies, could, when necessary, examine and report on from one to two thousand recruits per day. During one month the total number of psychological examinations in the camps approached three hundred thousand.

The results of psychological examining in the army have two particularly important bearings. Their primary significance is in connection with the development and improvement of methods of mental measurement which are applicable alike to industrial, educational, military, and other practical situations. Equally important, however, with the advance in the development of methods, are the scientific results of this extensive mental survey.

The most important single achievement of the group of psychologists which developed the methods for army mental 
testing is the creation of a practical, serviceable, and reasonably reliable method of group examining by which, if necessary, as many as five hundred individuals may be examined at one time.

The improvement in methods of individual examining due to the army work and experience is also extremely important, for more than eighty-three thousand individual examinations were made and the attention of a large number of expert examiners was concentrated for months on the perfecting of procedures and the increase of their practical military value. The Performance Scale for the examination of foreign and illiterate subjects, developed by army psychological examiners, has wide applicability. Like the group examination devised especially for subjects incapable of reading and writing English to any considerable extent, it marks a most significant advance in mental examining.

It is already evident that the contributions to methods of practical mental measurement made by this committee of the National Research Council, and by the psychological personnel of the army, are profoundly influencing not only psychologists, but educators, masters of industry, and the experts in diverse professions. New points of view, interest, and expectations abound. The service of psychological examining in the army has conspicuously advanced mental engineering, and has assured the immediate application of methods of mental rating to the problems of classification and assignment in our educational institutions and our industries.

If the full value of the labor on methods of mental measurement and the results of their use in the army is to be achieved, this work must be adequately reported and suitably published. The psychological staff of the Surgeon General's Office has made a tentative arrangement which promises to provide a satisfactory permanent scientific record.

It is proposed to prepare, first of all, a comprehensive official report of psychological service for the Surgeon General of the army and to recommend its publication by the Government. This report will present the history and organization 
of psychological examining in the army; an account of the methods as originally recommended, as revised, and as finally applied throughout the army; the history of the organization of the School for Military Psychology, and of the appointment training and assignment of the psychological personnel of the Sanitary Corps, and, finally, a summary account of the results of psychological examining and their values to the army, together with recommendations or report concerning the relations of this service to the permanent United States Army. It is believed that this report can be limited to approximately three hundred pages.

For scientific purposes, it is planned to prepare more detailed reports on methods and results which it is hoped may be published as memoirs of the National Academy of Sciences.

The initial volume, the manuscript of which is nearly completed, will consist of three parts: (I) An introductory description of the inception and organization of psychological service. (2) A detailed description of the methods of army examining in the various forms in which they have been tried out. This part of the volume will reproduce the directions for examination and the several examination blanks, together with all other printed materials, norms, and other standards of judgment which are essential for the proper understanding of the methods and their uses. (3) As a third part, it is proposed to present a complete account of the results of official trial of the methods in four National Army cantonments. This will include a description of the principal phases of the early organization of psychological service in the army and of the general relations of results of examining to revisions of method and extension of the work to the entire army.

In a second volume it is planned to present results of the examination of approximately $\mathbf{1}, 600,000$ soldiers. In addition to a general description of results, the volume will present a statistical study (based upon data secured with the Hollerith System) of approximately 200,000 records of examination chosen so that they adequately represent states, arms of the service, negroes and whites, and types of camp.

Finally, miscellaneous materials which cannot properly 
be placed in the preceding volumes will be published either separately or as a third volume. It is not improbable that these studies should be placed in psychological periodicals rather than the National Academy series. So far as the time of the psychological staff permits, these miscellaneous studies will present results bearing on such generally important topics as the nature and distribution of illiteracy among negroes and whites, and the relation of illiteracy to intelligence; the intelligence of the negro as compared with that of other racial groups; the relation of intelligence to geographical distribution and its significant bearings upon educational, industrial, and other social problems; the geographical distribution of intelligence in relation to the newly arrived or partially assimilated immigrant; the relation of intelligence to occupation and the significance of army occupational classification and intelligence ratings in connection with the practical problems of securing and utilizing mental specifications for vocational guidance; the mental characteristics of conscientious objectors and their significance for military service, educational activities, and social or governmental obligations. These are only a few examples of the miscellaneous studies which should be based on the abundant data of examination and special report available in the Office of the Surgeon General.

The preparation of the several volumes and special studies enumerated above is already well advanced. It is hoped that the volume on methods and initial results may be ready for publication early in the spring of 1919 and that it may be followed promptly by the volume on the analysis of results, the official report, and the more important of the miscellaneous studies.

The above plan, it is believed, provides as adequately as is now practicable for the publication of the results of military psychological service in the interests of the army and of other governmental agencies as well as of education and industry.

3. The Committee on Psychological Problems of Aviation, including Examination of Aviation Recruits, was authorized by the Council of the American Psychological Association. 
It was made a subcommittee of the Research Council in November, I9I8. Under the chairmanship of Harold E. Burtt, the committee, whose other members were W. R. Miles and L. T. Troland, undertook the selection and development of mental and physiological tests which promised a priori to be indicative of aptitude for flying. Various existing forms of apparatus were adapted for the tests and several new forms were devised and constructed. Although the primary intention was to proceed purely empirically to determine which tests were indicative of flying ability, it was also proposed to undertake the development of tests bearing on the mental and physiological state of the aviator during flight.

The evaluation of tests by trial on cadets at the Army Aviation Ground School, Massachusetts Institute of Technology, was begun early in June, I9I7.

The following tests were given:

I. Patellar reflex with two stimuli in succession, a gradually decreasing interval between stimuli.

2. Electrical threshold.

3. Cardiograms and records of respiration while reclining and while "chinning" oneself.

4. Finger movement; first and second fingers moving together as rapidly as possible through an uncontrolled distance.

5. Swaying; standing with a helmet beneath smoked paper.

6. Visual acuity; Ives gratings.

7. Memory test (Dodge's); words exposed one letter at a time.

8. Inhibition of winking reflex.

9. Eye reactions to light; moving from fixation point to a spot of light which appears.

IO. Speed of eye movements.

I I. Ocular pursuit movements; following pendulum.

I2. Reversed maze; tracing it visibly and then invisibly and rotated.

13. Association reaction with crucial words involving fear, falling, etc.

I4. Motor learning; learning a fixed series of reactions with two alternatives by trial and error.

I5. Auditory difference threshold with loud standard similar to the sound of a motor.

I6. Distance and velocity estimation; moving target passes across 
opening at constant rate and then disappears; the subject tries to stop it when it has reached (invisibly) a given point. 17. Continuous choice reaction; each stimulus being produced by the preceding correct reaction.

I8. Tapping with index finger vertically between two fixed contacts. 19. Equilibrium reaction time; subject sitting on platform which tilts suddenly; choice reaction to the direction of tilt.

20. Simple visual reaction time.

2I. Simple auditory reaction time.

22. Fatigue; ergograph with middle finger.

23. Emotional stability; changes in pulse, breathing and arithmetical performance as affected by a revolver shot.

About seventy-five cadets were given the above series of tests. Arrangements had been made to correlate test performances with records from the flying schools as soon as these men learned to fly solo and also when they received the rank of "Reserve Military Aviator." Unfortunately the exigencies of the situation in Europe interfered with this program, since it became necessary to send some of the men direct from the ground school overseas. Records of flying ability were obtained for twenty-five of the men tested.

In the summer of 1917 the committee was reorganized. Burtt resigned and George $M$. Stratton who had been working independently on tests for aviators at Rockwell Field, San Diego, was appointed chairman. Edward L. Thorndike was chosen as executive secretary, and John B. Watson, Warner Brown, Francis Maxfield, and H. C. McComas were added to the membership. Stratton had tested over fifty cadets in the following capacities: auditory reaction time, visual reaction time, emotional stability, steadiness and standing, perception of gradual tilt of the body as a whole, dexterity, and the power to continue in imagination certain segments of curves presented visually.

A combined score showed that of the six aviators who made the lowest scores, five men subsequently were relieved from flying because of failure to learn to fly. Stratton's results, together with the entire data of Burtt, Miles, and Troland, and later the findings of Maxfield, were pooled for comparative analysis under the direction of Thorndike, who under- 
took a statistical study of the relation between the results of the tests and the degree of success achieved in flying.

It was early foreseen that it would be necessary to select a number of tests, each properly weighted, as the practical means of predicting aptitude for flying. Provision was made by the army for a systematic and detailed tryout of promising tests by Captain Stratton and Captain Henmon at Rockwell Field and Kelly Field in coöperation with the Committee on Classification of Personnel. The personnel of the group on whom the tests were tried out included one hundred men chosen on the basis of their special skill in flying, one hundred chosen as relatively inapt at flying, and one hundred candidates of unknown ability. This work, carried on in the spring of 1918, resulted in provision by the War Department for further research by Captain Stratton, and the authorization of four special examining units to apply the tests to candidates for cadetship.

To Major John B. Watson of the subcommittee on aviational problem was assigned, in the summer of 1917, the task of organizing methods, other than medical, to be used by the examining boards for the selection of personnel. Watson also assisted in organizing a group of research psychologists to collaborate with physiologists and medical officers in the study of aviational problems at the Bureau of Mines, Washington.

Special mention should be made of the Psychology Section of the Medical Research Laboratory at Hazelhurst Field, Mineola, Long Island, which developed from the work inaugurated in Washington by Watson and his associates. At this station, Major Knight Dunlap ${ }^{1}$ was primarily responsible for the development of a series of psychological tests to assist in determining the ability of candidates for the aviation service to withstand the effects of high altitudes. Oxygen insufficiency was produced by the Henderson rebreathing ap-

${ }^{1}$ For an account of the psychological work of this station see Knight Dunlap: "Psychological Research in Aviation," Science, N. S., 49, 94-97, Jan. 24, 1919; "Manual of Medical Research Laboratory." War Department, 1918, pp. 163-199, and "Medical Studies in Aviation," (IV. Psychologic observations and methods.) Jour. Amer. Med. Assoc., 71, 1382-1400. Ocober, 1918. 
paratus, and the important resulting effects on attention and on voluntary sensory-motor coördination were made the basis of practical tests for rating aviators.

In general the method employed called for the performance by the subject of a group of continuous tasks involving coordinated reactions during the gradual decrease of oxygen supply. The composure of the subject and his ability to comprehend instructions were noted. Attention and motor tendencies were recorded on a fixed scale of types, as were also the moments when the effects of oxygen insufficiency attained a certain standardized importance, especially the final moment of 'complete inefficiency' which would have been followed quickly by a complete breakdown and unconsciousness if the reactor had not been given air.

The psychological section of the Mineola Station, at first under Major Dunlap and later under Major Stratton, trained and sent into the field units for administering these tests to aviation cadets. During the last half of $19 \mathrm{I} 8$, beside the conduct of psychological tests of the ability of aviators to withstand high altitude and the consequent lack of oxygen, further research was carried on for the discovery of special aptitude for flying. To this end, experiments were instituted at Taylor Field, Montgomery, Alabama, under the immediate charge of Captain McComas, and at Souther Field, Americus, Georgia, under the immediate charge of Lieutenant Bagby with special apparatus and methods in the following regions: The judgment of differing rates of motion which intersect, pursuit movements of the hand, the power to trace and retrace a given course, the strength and maintenance of a maximal grip, the time of complex reaction to visual signals. These experiments are now in progress and it is too soon to give their outcome even in summary.

J. F. Shepard coöperated with the subcommittee on aviation in devising tests for aërial observers. The Shepard method of modifying photographic plates is worthy of special notice.

Captain H. C. McComas of the subcommittee also conducted work along somewhat similar lines. 
H. L. Eno and O. V. Fry developed apparatus for measuring the aviator's ability to point his plane quickly and accurately in a desired direction, as at an enemy plane.

Major Watson was sent to Europe to gather statistics on the qualities essential to success as a military aviator.

Dr. Parsons of the Navy received help from the committee in giving tests to every candidate for flying status in the naval air service. Parsons' study of the relation of the duration of nystagmus after rotation to flying ability yielded negative results, which are corroborative of Thorndike's findings, and supported by Dodge's analysis of nystagmus reactions.

From August 4, I9I 8, Thorndike served as chairman of the subcommittee on aviation. The Department of Military Aëronautics had requested that he be designated as expert to prepare and put into operation methods of psychological testing appropriate for examining the personnel of that department. To that effect he studied the system used by the aviational examining boards for the selection of candidates in the air service and also the intelligence tests in general use in the army. Especially by modification and supplementation of the latter he developed a test of mental alertness to measure mental ability of the order requisite for success in the air service.

From the records of over two thousand flyers, Thorndike determined the relation between actual success in the work of a military aviator over the lines and age, social status, intellectual ability, business achievement, athletic ability, and many other characteristics.

A testing and rating plan, a part of the general plan for the selection and classification of officer material in the Students' Army Training Corps, was adopted by the Procurement Branch of the Personnel Section of the Air Service and was to have been put into operation in November, 1918, for the selection of over one thousand aviation cadets per month from the Students' Army Training Corps. ${ }^{1}$

4. Committee on the Selection of Men for Tasks Requiring

1 This account is supplemented by E. L. Thorndike: "Scientific Personnel Work in the Army," Science, N. S., 49, 53-61, Jan. 17, 1919. 
Special Aptitude.-This committee was organized with the following membership: James C. Chapman, Truman L. Kelley, Walter Dill Scott, Edward L. Thorndike, chairman. It was constituted a committee on 'Tests of special skill' by the Executive Board of the Research Council in November, I9I7.

Numerous problems of special skill dealt with by this committee ultimately led, through the activity of Thorndike and Scott, to the organization of the Committee on Classification of Personnel in the Army.

By request, the following summary account of the services of the Personnel Committee has been prepared for this report by Walter V. Bingham, Secretary of the committee. ${ }^{1}$

"The Committee on Classification of Personnel in the Army was created by Secretary Baker, August 5, I9I7, as an instrument to increase the value of the army's man-power through securing the most effective placement of each man. This has demanded an exhaustive study of the entire army organization to determine where ability of various kinds is required, and the development and supervision of an army personnel system to discover the occupational, educational and military qualifications possessed by the recruits and to insure their assignment to the proper units.

"The Committee was organized with Walter Dill Scott as Director, E. L. Thorndike as Chairman, and W. V. Bingham as Executive Secretary. The other members were J. R. Angell, R. C. Clothier, Raymond Dodge, H. L. Gardner, J. F. Shepard, E. K. Strong, Jr., L. M. Terman, J. B. Watson, and R. M. Yerkes. The places of five of the original members have since been filled by J. J. Coss, W. R. DeField, W. B. Hale, P. J. Reilly and J. J. Swan.

"A large force of able and devoted civilian and military associates of the Committee, in Washington, in the camps, and overseas, has made possible the realization of its plans.

"For this program an initial appropriation of $\$ 25,000$ was

${ }^{1}$ An official account of this work is in preparation for early publication by the War Department under the general title "The Personnel System of the United States Army." There will be two volumes: I. The Evolution of the Personnel System; II. The Personnel Manual. 
made, and as the scope of the Committee's responsibilities grew, additional appropriations were approved until the total amounted to $\$ 85 \mathrm{I}, 650$.

"While it happened that the original membership of the Committee consisted almost wholly of psychologists, many industrial and business specialists in employing, classifying, and assigning men were called upon to insure the successful prosecution of the work. This has included the following activities:

"(a) Classification and placement of enlisted men. Personnel offices have been established in all army divisions, depot and training camps, coast defense stations, aviation fields, special training camps, for Staff Corps and at other army posts. In these offices a special card system furnished accessible information as to the educational, occupational, and military qualifications of every man. With a minimum of clerical work this system selected 973,858 men for transfer largely into technical units in the Engineers, Aviation, Ordnance, and other Staff Corps, and even more men for transfer within the divisions or camps. Sixteen civilian supervisors, directed by the Committee, acted in an organizing and supervisory capacity in the field. Approximately 450 officers and 7,000 men were engaged in this personnel work. The number of soldiers interviewed by trained examiners and classified according to their best army usefulness was in all, approximately three and a half million.

"(b) The allotment branch or central clearing offce of the committee in Washington received reports on the numbers of skilled tradesmen found in each contingent of the draft, received and consolidated requisitions from the Staff Corps for specialists, and prorated these requisitions among the various camps according to their supply of necessary skilled men. On November II, requisitions for roughly 600,000 men of designated qualifications had been filled here. Information was available at any moment for the Operations Division of the General Staff concerning the occupational qualifications of all men in the several depot brigades, army vocational schools, and similar sources of supply. 
"(c) Trade specifications and index of occupations. Definitions of the many hundred different trades needed in our military establishment were prepared after exhaustive study, and were brought together in a book, "Army Trade Specifications." This index is an indispensable reference for Staff Corps and camp personnel officers in securing the skilled personnel needed.

"(d) Tables of occupational needs and personnel specifications. Tables were prepared showing in detail the needs for skilled workers in each sort of platoon, company, regiment, or other unit. These tables were studied, criticized, and approved by army units at the front in France, and later formed the basis for organizing quickly the newest divisions. Out of these occupational tables have developed the Personnel Specifications which have now been completed for the enlisted personnel of four hundred different kinds of organizations.

"(e) Trade tests. To increase the accuracy of selecting skilled workers among the enlisted men, a system of practical trade tests was devised, standardized, and installed in twenty camps. At the time of the armistice about I30,000 men who claimed occupational skill had been trade tested.

" $(f)$ Personnel work for officers. Qualification cards for officers, furnishing a record of occupational, educational and military experience and a rating by superior officers, were developed and put into use throughout the army. These cards are filed in Washington, and duplicates filed in the custody of the Division commanders for their own use in assigning their officers.

" $(\mathrm{g})$ Rating of officers. A uniform system of rating officers was developed. This rating system was first installed in the Officers' Training Camps as an aid in selecting candidates for commissions. Later it was used in selecting candidates for Officers' Training Schools. Now its use is universal both in America and in France as a means of securing every three months a rating on every officer as an aid in determining promotion, demotion, discharge, and appointments to the Officers' Reserve Corps.

"(h) Commissioned personnel specifications. Definitions 
of duties and qualifications of no less than 500 different kinds of officers in the various arms and branches of the service have been prepared, after ascertaining the answer to the question, "Just what does he do?" These commissioned personnel specifications are for use in recruiting officer material, in selecting men for training as officers, and making assignments. Statistical studies have been made of the relative significance of age, education, civilian earnings, intelligence and other qualifications of officers in the different corps and arms of the service.

"(i) Coöperation with the air service. The methods of selecting aviators were investigated and checked by reference to the actual success or failure of the pilots. An improved system of tests for aviation candidates was introduced and a new program of examination and selection installed.

"(j) Coöperation with the Provost Marshal General's Office. Plans for securing classificatory information regarding all registrants were submitted to the Provost Marshal General and were partially embodied in the draft questionnaire.

"(k) Development Battalions. The Committee coöperated closely with the General Staff and the Surgeon General's Office in preparing and introducing the plans for segregating, sorting, training, and utilizing the partially fit.

"(l) Coöperation with the Surgeon General's Office. Some assistance was given to the Division of Psychology of the Surgeon General's Office in devising and administering the intelligence tests for enlisted men and officers. The psychologists in turn have tested $1,726,000$ soldiers and furnished personnel officers with their intelligence ratings to assist in making assignments, balancing units, and selecting men for special responsibilities.

" $(m)$ Coopperation with the Navy. At the time of the armistice, representatives of this committee were assisting the Navy and the Marine Corps to prepare and install a complete personnel classification program to correspond with the army system. In addition, one member of the Committee has done valuable work in refining methods of selecting and training men for special dutics in the Navy, such as gun-pointing, 
hydroplane listening, the work of the fire-control squad, and the lookout.

"(n) The War Service Exchange. This branch of the Committee was established January I8, I9I8, to receive and classify applications of persons desiring to serve the government and to refer them to the branches of the service needing them, and to coöperate with other agencies in locating and supplying men needed for special purposes by the various branches of the service. This organization relieved high officials of the War Department of the necessity of devoting valuable time to the interviewing of the many influential men who came to Washington to offer their services to the government. It also cared for a total of about one hundred and ten thousand written proffers of service. It placed approximately ten thousand men, including many of superior attainments.

"(o) Personnel work in the American expeditionary forces. Members of the committee studied the personnel needs of the A. E. F., and with the cordial approval of General Pershing, established there a personnel organization similar to that in America. The Officers' Qualification Cards have had their widest usefulness overseas, in supplying replacements and in ocating rare specialists in emergencies.

" $(p)$ British experience. Detailed study was made of the working of the British personnel organization, which in some respects is far superior to ours. Special reports and exhibits obtained in London from the British War Office covered their whole program of recruitment, classification, trade-testing, assignment and transfer; industrial furloughs; weekly consolidation and analysis of strength reports; and plans for demobilization.

"This in outline is a picture of the Personnel work, begun in the National Army cantonments with the arrival of the first contingent of the draft. Neither the civilians nor the army officers who initiated this development dreamed of the scope it would so rapidly assume or the share it would have in effecting the speedy organization of a well balanced army, trained and ready for the critical hour in France. 
"The Committee on Classification of Personnel in the Army as such has disappeared. After fourteen months of service under the Adjutant General of the Army, it was transferred to the General Staff and merged with the Central Personnel Branch, newly created to supervise the procurement, placement, tranfer and promotion of officers throughout all branches of the army. This means that centralized control of personnel work for both officers and soldiers is recognized and thoroughly established as an integral part of the United States Army organization."

5. Committee on Recreation in the Army and the Navy.Originally authorized by the Council of the American Psychological Association, under the chairmanship of George A. Coe, this committee was organized with the following membership: William C. Bagley, Rowland Haynes, J. T. Patrick, J. H. Tufts, and the chairman.

On acceptance of his appointment the chairman formulated a plan of work which included important investigations and the establishment of profitable coöperative relations between his committee and the various civilian agencies concerned with recreational activities in military training camps.

Various unfortunate circumstances delayed the fulfillment of the original plan and it was finally decided that the Commission on Training Camp Activities and the Y. M. C. A. were satisfactorily meeting the urgent demands of the situation.

6. Committee on Problems of Vision which Have Military Significance.-Authorized in April, 1917, by the Council of the American Psychological Association, this committee was made a subcommittee of the National Research Council shortly after its organization. Its membership comprised R. P. Angier, H. A. Carr, L. R. Geissler, S. P. Hayes, G. M. Stratton, L. T. Troland, and Raymond Dodge, chairman.

The chairman of the committee most generously contributed his time and professional skill to the departments of war and navy. Since much of his practical work demanded secrecy and was imperfectly known even to the Psychology Committee, he has been asked by the chairman of the com- 
mittee to prepare for this report a summary account of his war service. This contribution, which follows, is one of the most interesting chapters of the scientific history of the war. It is more detailed than other sections of this report because practically nothing has been published heretofore on most of the topics.

\section{Report of Lieutenant Commander Dodge}

"The subcommittee on vision shared with some of the other subcommittees in Psychology the disadvantages of mutual inaccessibility. Questions that were submitted commonly required an immediate estimate for prompt action. There was neither time for nor expectation of a complete or final solution. The military situations that we had to analyze were not infrequently of a highly confidential character. In some cases the suggestion that the matters be referred to a committee for investigation met with quite emphatic disapproval. Moreover, the initial visual problems that we came upon commonly turned out to be so intimately related to non-visual factors that they became the least important part of the investigation. So it came about that in spite of the enthusiastic coöperation of a splendid committee, the committee form of partitioned investigations in our case proved impracticable during war times. We had to work as individuals at top speed.

"In the early psychological war problems in whose solution it was my privilege to participate, the conspicuous features were the failure of military authorities to appreciate the reality of the mental problems, even when they were the main problems of a situation, and the failure of military traditions to meet the new problems of human engineering which modern warfare occasioned. The great service of the military psychologist was to analyze out of the situations the human and mental problem, to give these phases of the military problems precise formulation and then to bring to bear his laboratory and scientific traditions in meeting the situations as they were analyzed.

"The military danger in the next few years of peace is 
that with the passing of the present crisis, so few military officers are capable of carrying on the mental researches. I fear that some other nation may take up the mental analyses where we left them when the emergency ceased, and may develop a real military psychology that will be more deadly than $42 \mathrm{~cm}$. guns. Our efforts, however excellent and however valuable, are only the first crude beginnings of such a military psychology.

"In reviewing my war work correspondence, it is interesting and instructive to note that while the practicable means of attack was often delayed for months, and the practical occasion for developing the problem was often quite unconnected with the inquiry from the Research Council, every one of my leads for service came first from the Research Council. Furthermore, in spite of some moments of personal discouragement and misgiving, not one of the inquiries that came to me in this way proved either useless or impracticable. It seems to me that this is a very high tribute to the wisdom of the guidance of our chairman and his colleagues of the Research Council. The only serious difficulty in the path of scientific service was the initial lack of confidence of the authorities. When confidence was once established, their faith in our ability to turn the desired tricks became an embarrassment, and the only limit to service was the limit of human endurance.

"The months that I devoted exclusively to national service seem in retrospect a kind of scientific excursion. The shadow of sorrow at their close comes from the fact that with the rotation of military service the old chiefs for whom we worked and would have followed to the death if necessary are being replaced by strangers who know nothing of our limitations nor our scientific potentialities.

"Shortly after the Committee on Psychology was organized, Chairman Yerkes referred to me as an inquiry from Dr. Mendenhall of the National Research Council the question whether we could recommend tests to select gun-pointers for merchantmen. The records of our efforts to answer that inquiry and of the vastly greater efforts to get our answer across 
are intensely human documents. The first was a relatively simple problem of analysis of reactions, adaptation of approved laboratory practice, and construction of a suitable recording device. Four days after the receipt of the inquiry I outlined the instrument that we used later, and I guaranteed its success. The second was a problem of salesmanship. Every gunnery officer who saw the instrument work was enthusiastic from the start, but it was months later before the official wall of suspicion and red tape was passed.

"On June II, I reported the construction and successful trial of an instrument to test gun pointers. It gave a series of graphic records of the fundamental processes involved in training a gun on a moving target, under as nearly service conditions as possible. Simple inspection of these graphic records, without elaborate computation, showed (I) the latency of beginning the training of the gun to a movement of the target; (2) the accuracy with which the actual movement of the target was followed; (3) the latent time of reacting to a change in the apparent motion of the target; (4) the effect on the aim of pressing the firing key; (5) the accuracy of the aim at the moment of discharge.

"This instrument was set up and tested on expert marksmen and inexperienced recruits of the U. S. S. Georgia and the U. S. S. Pennsylvania. The records show marked individual differences. The best gun-pointers gave the best records; the untrained recruits the poorest. But among the partially trained, some consistently followed the moving target with short reaction time and considerable satisfactoriness; some showed promising improvement within the five trials permitted.

"The instrument consists of an aluminum recording drum mounted on a horizontal axis. This is turned at an even rate through an arc of approximately ninety degrees by a weighted piston falling in a cylinder of oil with a predetermined by-pass. The weighted piston as it falls also moves the target in a horizontal plane. Thus the target starts when the drum starts and stops when the drum stops. A long recording lever (one meter) writes on the drum with a lead pencil. This lever is moved by the person to 
be tested in the endeavor to keep a hair line in the sighting telescope, which is mounted on the recording lever, on the center of the target. The reaction latency of the person to be tested is shown by the distance that the target and drum move before the recording lever starts. His accuracy is shown by the approximation of his record to a normal line which is recorded when the lever which carries the target is temporarily clamped to the recording lever. The moment of firing is indicated by the perforation of the record by a jump spark.

"The practical utilization of this instrument remained confined to the U. S. S. Georgia and U. S. S. Pennsylvania where it was tried out. It never got by the Office of Gunnery Exercises. Considerably later, I submitted a plan for a robust training model of this instrument to Captain E. L. Bennett of the Training Section of the Bureau of Navigation. The instrument was intended for shore training to offset the lack of dotter equipment in the naval training stations. Constructed by authority and at the expense of the Committee on Classification of Personnel, this instrument was set up in the Armed Guard Camp of the New York Navy Yard. It proved an instant success. Its use was developed to greatest efficiency at this place under Lieutenant Norton. Under orders from the Bureau of Navigation a number of replicas were built by the Armed Guard Camp of the New York Navy Yard for other training stations.

"The instrument consists of a battery of four skeleton guns, with training or pointing gear, a mechanism for giving the targets a series of harmonic wave motions of great variety and complexity, a recording device, that shows each movement of the target and the corresponding movements of the gun as the pointer or trainer tries to follow it, and a firing device, that not only indicates the accuracy of the pointing but also the effect of the effort to fire on the pointing coördinations.

"The object of the instrument is to furnish land conditions for teaching a recruit the coördinations of hand and cye essential to pointing and firing at a moving target at sea. It was designed as a robust practice instrument which could be repro- 
duced in any desired quantity at relatively small expense, and without demanding the services of expert machinists for construction. The graphic record was added to show the pointer and his instructor the relative adequacy of the pointing at each moment. The movements of the target, the sights, and the training mechanism were designed to duplicate actual service conditions as closely as practicable in simple construction.

"Successive records of the same recruit furnish a record of his progress in acquiring the coördinations necessary for gun-pointing. Gross incapacity or natural aptitude will be apparent in such a series. The instrument thus serves the double purpose of a shore-training device and a test by which marked natural inaptitude may be discovered with a minimum loss of time.

"Since the instrument is quite robust it is practicable for interested recruits to practice gun-pointing with it at odd times by themselves and without supervision. Experience with the instrument shows that the recruits do take an interest in it and use it practically continuously when permitted to do so.

"The base of the apparatus consists of a rectangular pipe framework, four feet high, six feet long, and two and one half feet wide. Each corner post carries an adjustable seat for the gun-pointer, and a skeleton gun. The latter is really a peep sight built into an iron pipe. This may be trained by a two-handed belt gear. At its muzzle end each skeleton gun carries a light but rigid recording lever, armed on its distal end with a soft lead pencil for making the records.

"The targets for the four guns are carried on a platform that moves across their line of action. The device for giving the targets an irregular series of harmonic wave motions corresponding to the movements of a floating gun-platform consists of a motor which drives a set of three wooden pulleys. The first pulley serves merely as a reducing gear. The second and third pulleys carry eccentric attachments to pull the target platform a greater or shorter distance, at greater or less velocity, according as they work together or in more or less complete opposition. The slack of the eccentrics is taken up by a long spring, which is attached to the target plat- 
form and works in opposition to the pull of the motor. As it worked out, this series of wave motions has been commented on most favorably by all the experienced pointers who have observed it. Without exception they have said that it was the best artificial target motion that they had ever seen on a dotter. By shifting the driving belt on the reducing pulleys, it is possible to imitate the movements of a slowly moving gun-platform or a rapidly moving one at will. Observers of experience name these speeds battleship roll, merchantman roll, and destroyer roll.

"Instead of moving the target platform directly across the frame, the track on which it moves is laid at an angle of forty-five degrees to the main frame. This makes the target travel the hypotenuse of a right isosceles triangle, of which the transverse leg would give the apparent displacement of the target from the standpoint of the trainer. The other leg in the direction of the axis of the gun furnishes the conditions for the record of correlated movements of target and gun. Thus a line traced by the recording lever which is attached to each gun and writes on a sheet of paper laid on the target platform, will represent point for point each movement of the target and the gun. If the gun remains stationary while the target moves, this record line will be an oblique line at an angle of fortyfive degrees to the gun axis. If the gun moves while the target is stationary, the record will show a straight line transverse to the axis of the gun. If the gun moves exactly with the target, that is, if absolutely accurate pointing is maintained throughout the movement of the target, the record will be a straight line in the axis of the gun. This latter is an impossible ideal of perfect pointing. All the records show a greater or less number of irregularities incident to the reaction time of the pointer and the imperfections of his coördinations. Improvement of the pointer in the essentials shows itself in the gradual reduction of the lateral displacements of the record from the theoretically perfect record of a single straight line. The record of each performance may be analyzed for the benefit of the recruit immediately after each trial. For this purpose, it is probably expedient not to have the practice records too long. Short records are less complicated and may be more easily analyzed. Moreover, the recruit can remember better what he did if the record is not too long.

"Following the recommendations of Lieutenant Norton, U. S. N., the instrument was adapted so that the targets could be given a vertical motion for practice in pointing as 
well as a horizontal motion for training. This was done optically by introducing a total reflection prism into the eye pieces of two of the skeleton guns. To reproduce for the gun-pointer the errors of his training mate, so that he could get practice in watching the vertical wire while firing, an artificial training error was introduced mechanically at fixed points of the motion of the target platform. At first thought this would seem to give the training error such a mechanical constancy that it could be predicted and therefore ignored. This is absolutely not the case. It follows the non-predictable character of the main displacement of the target, because the arbitrary training error will appear at every phase of the more or less extended movements of the targets, while on the records they will appear only in homologous parts of the curves.

"Firing records are introduced in the pointing records by pressing an electric button, which closes a circuit operating a small electric bell, only instead of hitting the bell, the buzzing armature hits the pencil holder. This makes a dot on the records when the gun is standing still, and a waved line instead of a simple line when the gun is moving. The firing will be perfect only when these dots and waves appear on a straight line along the theoretically perfect pointing line, at those parts of the record that are free from the artificial training errors.

"The artificial training error is produced by placing irregularities on the track of the target platform, over which a friction wheel glides. This is attached to a series of levers that add a vertical motion to the main horizontal movements of the targets. Since the optical system transforms the horizontal motion into a vertical one for the pointer, it transforms these slight vertical movements of the target into errors of training.

"The actual uses of the pointing instrument will probably vary according to the needs and inclinations of the groups for which they are available. Quite tentatively, I suggested the following: Entirely raw recruits should probably be introduced only to the training mechanisms, without recording all 
their trials. The instructor can see all the main features of the training errors. Occasional regular records should be taken at this stage only to show the rate of progress or as the mechanical proof of the judgment of the instructor that the recruit was or was not fitted to go on. Probably the men who make the best progress, or some proportion of them, should then be introduced to the firing pointer's more complex coordinations. Each group should be encouraged to practice by themselves without records. The formal records of each group should be posted to stimulate competition. Each record should have the benefit of individual criticism. The records of the trainers will show if the recruit's attention lapsed; if he got mixed up in the manipulation of his gears; if he started too slowly; if he tried to beat the roll; if he was irregular and jerky-as well as the accuracy of his training. The records of the pointers will show similar faults in the pointing coördinations, and in addition, if he fired when the vertical wire was off; if he stopped pointing to press the firing button; if he failed to fire when on; if he fired off; as well as whether he failed to "follow through" sufficiently long after pressing his firing key.

"Undoubtedly others besides raw recruits would profit by occasional graphic records and their criticism, especially those whose work at actual target practice failed to give evidence of adequate coördinations.

"The following letter from Rear Admiral L. C. Palmer was a very welcome summary of the naval estimate of the instrument:

\section{Navy Department, Bureau of Navigation, Washington, D. C., March 4, 1918}

My dear Professor Dodge: This Bureau is in receipt of an offcial report from the Commanding Officer of the Armed Draft Detail at the Navy Yard, New York, containing a description of an instrument devised by you for the primary purpose of selecting from among recruits those who are naturally fitted for training as gun-pointers.

The report indicates that in addition to fulfilling its primary purpose, the instrument has proven of great value as a device for 
training selected men, both as gun pointers and gun trainers. In this connection the report says in part:

'This instrument has been in constant use now for over a month. During this time it has been found to be of great value, not only for classification of pointers, but further, for their actual training. Despite the almost constant use of this machine by different persons, no parts have become worn out or broken. It further has the most important advantage of being popular with the personnel who are being trained, and it has been found that the enlisted personnel make use of this instrument upon their own volition outside of drill periods. The motion of the target, derived by the design of this instrument, is by far the best the Commanding Officer has ever seen, and this opinion is supported by various other officers who have experimented with it. The diagram which is obtained from each pointer or trainer tells precisely how close to the target the man has kept during his period and further whether or not he fired when on. The records of these pointers or trainers are kept from day to day and one is soon able to tell whether or not the individuals will ever pick up the necessary requisites for efficiency as such.'

You may be further interested to know that the Bureau has taken steps to have the experimental instrument reproduced and furnished as a standard training device for recruits at all large training camps.

I beg to take advantage of this opportunity to express to you our sincere appreciation of the value of what you have done and are doing to assist in the very heavy burden imposed upon the Bureau in the present emergency; and I may add that we are also deeply sensible of your spirit of unselfish devotion to the cause which we all have so deeply at heart. You have given us most freely of your valuable time and have, I suspect, made other personal sacrifices of moment, and have declined to consider any method of compensation. I hope that this wholly unsolicited expression of the Bureau's gratitude will not be quite unwelcome.

I am taking the liberty of sending a copy of this letter to the President of Wesleyan University.

Again thanking you, I am

Sincerely yours,

(Signed) Leigh C. Palmer, Rear Admiral, U. S. Naøy, Chief of Bureau 
"While we were trying out our instrument for testing gunpointers it became increasingly evident that the problem of picking prospective gun-pointers was regarded by most naval officers with whom I came in contact as only one of a group of interrelated problems of picking the most suitable men for the various tasks of the Navy. This was first emphasized by Lieutenant Mayo of the U. S. S. Georgia; then by Captain Plunkett of the Office of Gunnery Exercises, and by Commanders Bingham and McClintic, and Lieutenant Shannon of the U. S. S. Pennsylvania.

"In view of these reiterated suggestions, and in view of the wide scope of the permission granted me by the Honorable Secretary of the Navy to visit the fleet for analysis of the naval tasks, I undertook to do for the plotting room what I had done for gun-pointing. After observing the various tasks of the plotting room, I tried to reduce them to their simplest psychological terms, then to devise corresponding test methods, and finally to combine them in a single form or blank that would disclose at a glance, without elaborate computation, the relative fitness of the several recruits for plotting room service.

"The tests finally recommended were: the ability to repeat clearly by telephone a series of ordinary commands that were received by telephone, the ability to remember and repeat numerals, to read a circular scale, to read a plotting scale and to lay off distances to scale, together with neatness and accuracy in drawing and subdividing simple geometrical figures. All these data, except the telephone test were arranged on a single blank which could be estimated at a glance as good, medium, and poor.

"It proved impracticable to follow the history of this test, to work up the correlations between test and performance, or to modify the test according to experience. I was informed later that the tests, substantially as originally submitted, were adopted throughout the Atlantic Fleet for the selection of men for the plotting room, and that they were saving a great deal of time and trouble.

"A plan was submitted at the same time for a more ex- 
haustive series of tests for a considerable variety of naval tasks based on an analysis of the tasks. This plan would probably have been carried out to some degree at least, if the armistice had not cut short our naval 'career.'

"The connection between the subcommittee on vision and the Listeners' School is not altogether clear even to myself. But we were not fastidious in the selection of tasks provided they would help win the war.

"One of the minor but necessary tasks of the Training Section of the Bureau of Navigation was to find properly equipped men for the new Listeners' School without robbing other training schools of their regular quotas. It was a relatively simple problem in the economy of human material and personnel, but one for which no data were available. At the request of Captain Bennett, U. S. N., Chief of the Training Section, I analyzed the requirements of the Listeners' School.

"On the basis of that analysis, I elaborated a series of tests for candidates for the Listeners' School and was sent to various training stations to pick students from the enlisted personnel. After correcting the tests from the school experience with the first few quotas, I was able to make a detailed recommendation for the examination of candidates. With the cordial assistance of Naval medical officers in the several Districts, these tests afforded the Listeners' School a selected student personnel from which 80 per cent. to 95 per cent. of each class passed the course, all without seriously affecting the supply of suitable men for other naval schools.

"Without divulging anything that might be regarded as a military secret, the general plan of the tests is indicated in the following statement which has already been published by authority of the Bureau of Navigation.

I. Candidates for the Listeners' School were selected by the following processes:

(a) Their Navy record in the Training Station.

(b) Their education (or other indication of intelligence).

(c) A special medical examination.

(d) A group elimination examination.

(e) An individual stethoscope test.

(f) A final compensator test. 
2. All candidates for examination are selected by their officers. Candidates must have:

(a) The general training of a seaman, especially military discipline, care of a seaman's belongings and person, and the ability to handle firearms effectively.

(b) General intelligence sufficient to profit by an intensive course of school work.

(c) Loyalty to and interest in Naval work.

(d) Enough self-reliance and initiative to carry the responsibility of the Listeners' task.

(e) Enough team -spirit to make him livable in cramped quarters.

3. In the absence of other clear indications of the requisite general intelligence to profit by the intensive course of school training required of Listeners $(2 b)$, it is required that candidates have at least two years of high school. Other indications of superior intelligence would be a record of success at some electrical trade, or some business where the candidate had given evidence of superior mental ability.

4. The medical examination of candidates emphasizes the integrity and normal functioning of the auditory apparatus, with less emphasis on the visual equipment.

5. The group elimination examination aims to eliminate from the group selected by their officer those men who are least fitted for the special tasks of the listener.

The ideal examination would probablv be to try out every candidate with the special apparatus used under the actual conditions of service. Since that seems to be impracticable, a set of tests had to be developed that would correspond to those tasks as closely as possible. After a considerable experience with the men selected by these tests, consequent to which the tests have been checked and corrected, it seems important to give them as uniformly as possible in all Naval Districts, and to make no intentional change either in substance or method until that change has been fully considered by the Bureau of Navigation and checked by correlation with the actual work of the men at the school.

6. The mental test consists of four parts.

(a) The memory span for 4-, 5-, and 6-place digits.

(b) The ability to read a circular scale to an error of one degree.

(c) The ability to locate the source of sounds from behind a long horizontal screen.

(d) The ability to discriminate between softly spoken or whispered syllables and nonsense words. 
7. Candidates who reach a grade of 75 per cent. in this elimination test are given an individual examination in their ability to discriminate phase difference, with a stethoscope attached to a rubber tube. This individual test also serves the following purposes: (a) To check other sources of information covering the candidate's personal qualifications. (b) To estimate the quickness and certainty of his reactions.

8. The final process in the selection of candidates for the Listeners' School was conducted by myself. In this examination it is assumed that all candidates have the minimum qualifications detailed above. No regular effort is made to check these qualifications except in the matter of schooling. Before examining a candidate a brief typewritten statement of instructions is given to him. Failure to understand or to follow these instructions leads to a more careful review of the candidate's general intelligence.

9. The purposes of the final examination are:

(a) To serve as a check on the preliminary elimination in the several Naval Districts and to standardize the results. That is: it sometimes happens that in filling its required quota one District is compelled to include some men of a relatively low grade. By comparison of all the candidates at one place it is possible to apply a common standard irrespective of the Naval Station from which they came.

(b) To estimate a number of factors that could not easily be tested without special training and apparatus.

Io. The instrument used for making the final examination is a simplified compensator designed for the purpose and is constructed as follows:

On a suitable standard two concentric wooden wheels are mounted. One wheel facing the examinee measures thirty $\mathrm{cm}$. in diameter. This is his compensating wheel. The compensating wheel is operated by the examinee as though it were a real compensator. The other wheel just behind the standard and hidden from the view of the examinee measures $26 \mathrm{~cm}$. The position of this wheel determines the difference in wave phase. It carries on its periphery the middle third of a rubber tube which is two meters long. The ends of the tube are carried through the hollow axis of the whecls to a stethoscope. The exact middle of the tube is plainly marked on the operator's side, and the tube is cemented firmly in place on the wheel. The concentric wheels can be turned independently to prevent secondary identification marks. Slight 
friction in the bearings prevents any accidental lag. A noise roughly approximating the revolution of a submarine propeller is produced by rubbing the tube lightly with a bare lead-pencil lead. If a circular motion is given to the lead the number of revolutions as well as the noise quality can be imitated.

II. The candidate after reading his instructions sits at a table opposite the operator with the simplified compensator between them while the operator rubs the rubber tube at some arbitrary height above the table with the naked lead of a lead pencil. The candidate rotates his compensator wheel until the sound seems to be dead ahead. If the localization is perfect the center of the tube should be directly under the operator's pencil.

I2. Preliminary trials must always be insisted on until the examinee has a clear idea of his task. If there is any indication of failure to understand the task the candidate is verbally instructed by the operator. But if inability to understand the task, inability to learn the direction in which the wheel must be rotated, or if gross faults of manipulation are persistent, the candidate is eliminated. The practice is to permit any failing candidate to repeat his examination at any later examination period as long as he is still eager to do so. Eagerness is a good indication. Unfortunately only about one candidate in twenty is able to better his record materially.

I3. If a candidate locates the center within an average error of one cm., quickly, consistently, and without gross variations, he is passed by the examiner. If there is any persistent difficulty a static localization test is given, in which the following points are noted in four grades of excellence:

(a) Right or left displacement of the center.

(b) Breadth of the center.

(c) Consistency of the reactions.

(d) Quickness and sureness of reaction.

If the candidate passes this test he is then given another active compensation test.

14. A strict watch is kept by the operator for disqualifying personal qualities. No grouches, boneheads, discontented or notably immature candidates are knowingly sent on to the School.

"The success of this selective process has a rather interesting theoretical bearing. The task obviously lay outside my proper field, as I do not pretend to know the psychology of audition. Perhaps this was not a serious handicap since

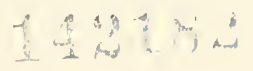


if we had depended on our psychological traditions of the localization of sound we would have missed the point of the new localizing apparatus. As a matter of fact, I followed here as elsewhere the general principle of using a replica of the actual task for test purposes instead of any presumptively correlated tasks. The results seemed to justify the method. I believe that it is theoretically sound.

"In the spring of I9I 8 the Chemical Warfare Service of the Bureau of Mines made specific inquiry through the Research Council as to the importance of certain visual limitations of the standard production mask. ${ }^{1}$ The matter was referred to me, and after consultation with various members of the Service, I undertook to answer the inquiry, and was appointed Consulting Psychologist. From the moment that I put on a mask it became obvious that the visual conditions of tenancy interacted with various psychological and physiological conditions.

"My report on the visual factors which are involved in continuous tenancy of gas masks aimed to summarize the relevant traditions of physiological optics, laying especial emphasis on the military advantages of peripheral vision, and discussing the relative faults of various windows, with respect to both material and position. Experimental investigation took a more general form.

"Relative to the total complex of tenancy problems, I suggested a combined investigation of the respiratory, metabolic, neuro-muscular, visual, and psychological effects of the gas mask. The obvious place for such an investigation was the Nutrition Laboratory of the Carnegie Institution, Boston. The plan met the cordial approval of the Chemical Warfare Service. In spite of probable interference with other forms of patriotic service, the Director of the Nutrition Laboratory generously gave the investigation the hospitality of the Laboratory, and authorized such help as his collaborators and assistants found it practicable to give. Very unfortunately, as I believe, the coöperative investigation failed to get started.

${ }^{1}$ This statement of Lieutenant Commander Dodge is supplemented by the data in section $15, \mathrm{p} .14 \mathrm{I}$, of this report. 
But in spite of many difficulties the psychological program was initiated and carried through a month of intensive work.

"Throughout the investigation the subject was myself. A number of circumstances made this somewhat questionable procedure necessary. In the first place, I needed first hand information of the effects of the mask. Moreover, in my own case there was available abundant data on the normal variability of my responses. So I could evaluate a few experiments on myself better than on an unknown subject. Finally, the lack of available assistance made it impossible to begin in any other way.

"The observations were of two sorts: (I) A serial record of personal impressions. While this was quite inexact and liable to distortion by personal bias, it was the only criterion in matters of relative comfort and discomfort. Moreover, for an observer who is trained to avoid the commoner illusions of self-observation, the method will give considerable insight into the presumptive facts over a wide field. (2) In addition to these personal impressions, quantitative measurements were made of a group of selected processes that seemed likely to be significant on psycho-physiological or military grounds.

"When the investigation began there was no available tradition of the probable effects of gas-mask tenancy. Based on the previous studies of fatigue and of the psychological effects of alcohol, I selected the following processes for measurement:

I. The duration of the pulse and respiration cycles during rest, measured work, and the recovery after work. Pulse is the bestknown indicator of general physiological condition. Our pulse records were electrocardiograms.

2. Visual acuity as measured by the grating test object. The relation of visual acuity to military efficiency needs no comment.

3. Simple reaction of the hand to a visual signal. This was undoubtedly too simple a form of reaction, but no suitable military task seemed available on short notice.

4. Eye reactions were photographed by the usual technique. They are involved in every adjustment of a soldier to events that he can see. It is a more complicated form of reaction than the simple finger reaction, is more universally practiced, and probably more significant in its changes. 
5. The velocity of eye-movement. This is also a universal factor in adjustment to seen events. But it seemed important for other reasons. Dependent on the nice coördination of the orbital muscles, it is very sensitive to disturbances of the central nervous system.

6. The speed of the oscillations of the fingers. Like the eyemovements, it is a kind of coördination test with simple technique, and a flat practice curve.

7 . The hand dynamometer. Frankly this was a makeshift. We expected to discard it for the Martin strength tests as soon as Lieutenant Richmond arrived. ${ }^{1}$

8. Continuous addition, a simple form of continuous work test with controlled association.

"The most consistent and largest effect of gas-mask tenancy was decrease of visual acuity, an average of 20 per cent. Addition was slowed 7 per cent. Eye-reactions were longer by 9 per cent. Eye-movements were 7 per cent. slower. In lesser degree the finger reactions, finger movements, and dynamometer strength tests were adversely affected, three, two, and one per cent. respectively.

Inspection of the curves for the several days shows a progressive adaptation to mask conditions that corroborates personal impression. This adaptation was both general and specific and seems to be of the utmost military importance.

"Of vastly greater importance than the fractional falling off in efficiency of the various processes was the effect of improperly made or improperly fitted head gear. Within one hour I had reached a degree of discomfort from an ill-fitting head gear where in spite of experimental interest in the task, in spite of patriotic sentiment, and all the scientific pride I could muster, I could stand the punishment no longer and simply took the mask off. The extreme military importance of such a condition of mind seems clear. A properly constructed and properly fitted mask can be worn almost indefinitely, after adaptation.

"It was officially reported that our study and the recom-

${ }^{1}$ This officer of the Sanitary Corps, psychological service, had been ordered to report to Lieutenant Commander Dodge for duty as assistant in the gas-mask investigation. He received his orders too late to be of service. 
mendations that grew directly out of it were of substantial help in developing the modern mask. For military reasons I have deleted all reference to the several types of mask and their relative advantages as measured by our tests. I would record in this formal way the help of my assistant, Mr. Vincent B. Coffin, and the helpful counsel of Dr. Walter R. Miles.

"The last problem that was taken up concerned the condition of effective anti-submarine lookout service. This was one of the first questions that was suggested in the spring of 1917. But it was not until the fall of I9I8 that official recognition of its importance made a practicable opening for taking it up seriously. When Commander Coffey, U. S. N., was assigned to command of the Eagle Boats he requested authorization of a School for Lookouts in connection with the training of the officers and men of those boats. After a preliminary survey a satisfactory plan was drawn up and the school was authorized by the Bureau of Navigation. It was to facilitate psychological work in connection with this School that I was commissioned in the Naval Reserve Force. There followed in succession, a first-hand analysis of the tasks of a lookout, authorization of a plan to collect the most approved naval practices of our own and foreign forces, organization to investigate aspects of the task on which naval tradition and scientific doctrine seemed least adequate, the elaboration of a course of instruction and the preparation of a manual on the School of the Lookout, and the development of new training devices and apparatus. All these processes had reached substantial development before the U-boat warfare suddenly stopped at the signing of the armistice, and I was released from active duty to resume my academic work. The open publication of any of this work is obviously impossible for reasons of military expediency.

"By request of members of the National Research Council or Naval officers, memoranda were prepared on: (I) the relative advantages of binocular and monocular glasses for lookouts; (2) differences in the vulnerability of different kinds of firing reactions to emotional disturbance; (3) an examination for the admission of candidates to the Pay Officers' School; 
(4) the training of college men for the Naval Reserve Force, and other topics."

7. Committee on Pedagogical and Psychological Problems of Military Training and Discipline.-When this committee was authorized by the Council of the Psychological Association. Charles H. Judd was designated as chairman. He subsequently resigned, without organizing the committee, and on request of the Psychology Committee of the Research Council, William C. Bagley accepted the chairmanship. He secured the coöperation of A. Caswell Ellis and C. H. Judd as members of the committee.

In March, 1918, Bagley obtained from the Carnegie Foundation a grant of five hundred dollars for the study of conditions and methods of military training in typical camps. Truman L. Kelley and William R. Harper assisted the chairman in the conduct of this initial survey.

Preliminary reports from two camps indicated the desirability of scientific observation and practical assistance in connection with military training. It was thereupon arranged that Major Karl T. Waugh, psychologist at Camp Gordon, Georgia, should coöperate with the committee in an attempt to improve the procedure of military training and discipline. His work led directly to practical results, since officers of the line appreciated the existence of psychological and pedagogical problems and the value of expert advice for the improvement of training.

Unfortunately the work of this committee was so long delayed by failure to achieve satisfactory coöperative relations with the War Department and to obtain adequate financial support, that nothing was accomplished aside from the observational work in the above mentioned training camps and the holding of two conferences which proved to be of notable importance to the work of physical and mental reconstruction.

By request, Major M. E. Haggerty has prepared an account of these conferences as a part of his summary report on psychological service in reconstruction, which is printed below.

"In February, I9I8, Major Haggerty reported to the Surgeon General for duty and was assigned to the Division of 
Special Hospitals and Physical Reconstruction to organize psychological service for the reëducation of disabled soldiers.

"At his request IV. C. Bagley arranged a conference on psychological problems of reconstruction, under the auspices of the National Research Council. The conference, which was held March i I to I6, was attended by W. C. Bagley, J. W. Baird, B. T. Baldwin, Mabel R. Fernald, S. I. Franz, F. N. Freeman, M. E. Haggerty, E. K. Strong, Jr., R. M. Yerkes, and Helen T. IVoolley.

"To this conference Major Haggerty presented a memorandum on psychological problems in the reëducation of disabled men. The principal problems designated were: (a) the problem of mental attitude; $(b)$ the problem of functional reëducation; $(c)$ problems involving social, vocational, educational adjustment; and $(d)$ general problems of learning involved in educational work for disabled men. These groups of problems were assigned to subcommittees, with the understanding that reports should be submitted promptly. The reports proved valuable for the organization and development of psychological work in reconstruction.

"For further discussion of the problems of mental attitude a second conference was called by Chairman Bagley at the National Research Council April 8 to Ir. The members of the conference were W. C. Bagley, J. W. Baird, Ida Cannon, B. T. Baldwin, T. H. Haines, M. E. Haggerty, E. G. Brackett, and Kendall Emerson.

"As a result of these two conferences a program was formulated and presented to the Surgeon General. This led directly to the authorization by the Surgeon General of the assignment of a psychologist to the Walter Reed General Hospital. Major B. T. Baldwin reported for duty at that hospital April 17, I9I8.

"This was the beginning of psychological service in military hospitals. In the course of work at Walter Reed and other General and Base Hospitals where psychologists have since been assigned, the original program formulated in the conferences has been considerably altered. One of the most important developments is the organization of the psycho- 
logical service as an integral part of the educational work of the hospital. This new organization, known as the Educational Service of Military Hospitals, includes practically all extra-medical and extra-surgical activities carried on in the institution for the benefit of patients. In many instances even civilian agencies, such as the Red Cross, work through the Education Department.

"As now definitely organized, the Educational Service includes a Psychological and Statistical Division. The personnel of this division in most instances consists of from one to four commissioned officers, from two to ten enlisted men, and one or more reconstruction aides. The functions of the psychological service as defined by the Educational Officer's Handbook are as follows: (I) to have primary responsibility for psychological and educational surveys of individual patients; (2) to coöperate with other educational and medical officers in the study of special learning problems encountered under the curative workshop schedule; (3) to have coöperative responsibility for all measures intended primarily to direct and control the mental attitude of patients; (4) to have responsibility for all statistical studies of procedure under the curative workshop schedule; (5) to have coöperative responsibility for professional training and advancement of educational staff and of teachers in training.

"There are at present engaged in this service in fortythree different hospitals, 66 officers of the Sanitary Corps, 72 enlisted men and approximately Io reconstruction aides. Twenty-one of the commissioned officers are serving as Chief Educational Officers.

"Thus far the greater part of the work of this personnel has been the interviewing of patients who are subjects for the educational work of the hospitals. The facts obtained in these interviews are made the basis of all educational work prescribed for patients. They are reported on the Physical Reconstruction Register known as Form 58, which is transmitted to the Office of the Surgeon General on discharge of the patient.

"The essential features of this register are as follow: (a) 
diagnosis of patient's ability and a medical officer's prescription for curative work; $(b)$ educational and occupational history of the patient; $(c)$ psychological examination covering general intelligence, special aptitudes, mental attitude and ability to learn; $(d)$ the interviewer's recommendation as to future occupation and immediate training; $(e)$ assignments to curative work and data on the progress of the case.

"The program for practical work on mental attitudes as formulated in conference has been developed and modified in accordance with the following scheme, the characteristics of which are indicated below by the principal lines of endeavor: (I) development of objective attitude, (2) development of attitude of self-confidence, (3) development of the attitude of individual responsibility, (4) development of the attitude of social acceptability, and (5) developing the rationalizing attitude.

"As matters have developed, the most important single agency for the direction and control of the mental attitude of hospital patients has been the Reconstruction Aide in Occupational Therapy. Approximately one thousand of these aides, all of whom are women, are now engaged in domestic and overseas hospitals.

"Originally the occupational aides devoted themselves to teaching handicrafts and the work began with what seemed to many individuals trivial forms of occupation, but as it progressed, new forms have been developed and important changes have occurred. The following is a list of the chief groups of craft work now taught in military hospitals: (I) work with textile materials, as, for example, in weaving, knitting, crocheting, netting, knotting, embroidery, and rug making; (2) reed, cane and fiber work, as in basketry, chair caning, etc.; (3) woodworking, as in carving, toy making, joinery, etc.; (4) cardboard construction and binding, as in bookbinding, novelty box work, paper folding and pasting, etc.; (5) work in applied pattern; (6) metal work; (7) work in plastic materials; (8) leather work; and (9) work in drawing, lettering and designing.

"Reconstruction aides are now engaged, in addition to 
the teaching of crafts work, as teachers of commercial arithmetic and technical subjects. The chief value of the crafts work in military hospitals is psychological. The other subjects have strictly educational values.

"In this connection there should be mentioned the services of psychologists in measuring the progress of improvement in voluntary movement of disabled joints. This work, which was initiated originally at the Walter Reed General Hospital under the immediate direction of the late Professor Baird, has been introduced in several other military hospitals.

"A recent addition to the personnel of the Educational Service is the medical social worker, who has been brought into the hospital through the Psychological Division as a direct result of the second conference called by Chairman Bagley. The position of the social worker is now definitely established and her duties defined by a circular letter of instructions issued by the Surgeon General on January I8, I9I9. From this letter the following sentences are quoted to indicate the scope of her service: 'It is thought that Reconstruction Aides operating as medical social workers may be available: ( $\mathrm{I}$ ) in assisting to coördinate the various educational and related activities within the hospital so that they may serve a larger number of patients more efficiently; (2) by bringing to the attention of outside agencies, such as the Home Service of the Red Cross, the Y. M. C. A., the Knights of Columbus, the Jewish Welfare Association, the Federal Board, etc., the cases of soldiers who are in need of the types of service which these agencies are prepared to render; (3) in assisting medical officers as desired to secure such personal and social data about the patient as will assist in accurate diagnosis; and (4) in rendering such other services as may be assigned to them ...."'

8. Committee on Psychological Problems of Incapacity, including those of Shell-shock and Reëducation.-The Council of the American Psychological Association originally authorized this committee under the chairmanship of S. I. Franz, and also a Committee on "Psychological problems of vocational characteristics and vocational advice" with J. B. Wat- 
son as chairman. By request of the chairmen, these two committees were combined under the above title and the following membership was arranged: K. S. Lashley, J. B. Watson, and S. I. Franz, chairman.

The activities of the committee continued to August 4, 1918, when it was reorganized with the same membership as a subcommittee on "Problems of Reëducation."

Assistance was afforded the War Department by this committee in the following directions: (a) Systematic instruction of neuro-psychiatric groups in the work of rehabilitation by Franz at St. Elizabeths Hospital; (b) the development and application of methods for the reëducation of aphasics and paralytics (report on this subject is being prepared for publication by Franz); (c) conduct of investigations on the effect of injury to the brain, with special reference to the relation of experiments on monkeys to cerebral war injuries; $(d)$ arrangement with the Medical Department of the Army for the preparation of motion pictures of animal and human subjects to illustrate varieties of incapacity; $(e)$ preparation of a program for reconstructional experimentation which was subsequently presented to the Chief of the Division of Special Hospitals, Office of the Surgeon General; $(f)$ Coöperation with Major Haggerty of the Division of Special Hospitals in the formulation of plans and the preparation of methods for psychological service in reëducation; $(g)$ Lashley of the committee extended Franz's reëducational studies to crippled children and also conducted investigations on animal reëducation after cerebral extirpation and the reacquisition of muscular control after cerebral lesions.

No one of the above lines of service or research can be adequately reported here, but it is understood that suitable accounts of the work will be published in scientific periodicals.

9. Committee on Problems of Emotional Stability, Fear and Self-control.-As originally organized this committee of the American Psychological Association consisted of W. B. Cannon, G. S. Hall, J. B. Morgan, J. F. Shepard, and R. S. Woodworth, chairman. In August, 1918, it was reorganized as the subcommittee on problems of emotional fitness with the fol- 
lowing membership: E. G. Boring, H. L. Hollingworth, and R. S. Woodworth, chairman. Important assistance was rendered the committee by Captain A. T. Poffenberger, Major J. W. Hayes, and Dr. Josephine Curtis Foster.

This committee set itself the peculiarly difficult task of devising means which should aid in the prompt discovery and segregation of recruits whose emotional characteristics indicated unfitness for military service. A Personal Data Questionary was devised. Subjects, examined in large groups, were required to answer by "yes" or "no" a series of personal questions intended to disclose psychopathic or neuropathic tendencies and such emotional instability as might result in breakdown under the strain of warfare. Men answering a considerable number of these questions in the atypical way were to be referred for intensive neuro-psychiatric examination. No single unusual answer to the questionary was to be interpreted as indicative of psychoneurosis or neurosis, since each manifestation inquired about is reported by an appreciable proportion of presumably normal individuals. But the larger the number of such manifestations the more probable would it be that the individual has serious neurotic tendencies.

The correctness of this initial assumption was established by careful trial of the preliminary form of the questionary. One hundred and sixteen questions of the original list survived a thoroughgoing inquiry by a joint conference of psychiatrists and psychologists who passed on the statistical validity and genuine practicability and value of each question as shown in the preliminary trial on one thousand men at Camp Upton and on various groups of psychoneurotic and psychotic subjects. For example, any question was eliminated on the ground of doubtful significance which failed to separate individuals into a large majority, presumably of normals, and a small minority of atypicals, insofar as the characteristic under consideration was concerned. Judged by this criterion the following questions were among those found significant: Do you feel sad or low-spirited most of the time? Are you ever bothered with the feeling that people are read- 
ing your thoughts? Did you ever walk in your sleep? And the following were for like reason rejected: As a child, did you have dreams that frightened you? Have you ever been engaged to a girl? Do you like to be the leader in whatever is going on?

The conference of psychiatrists and psychologists, at which the questionary was revised, authorized the printing of twelve thousand copies which were to have been placed in immediate use at several camps. Cancellation of drafts and the termination of psychological service in the field prevented the complete execution of this plan. Important results were obtained from the examination of five hundred negro recruits, from about five hundred soldiers invalided home from overseas for nervous disturbances and examined at General Hospital number 30 , and from neuro-circulatory asthenics at Camp Upton, as well as from normal subjects.

Work on the Personal Data Questionary will continue, at first in the direction of determination of norms, since the method undoubtedly possesses considerable value as a means of discovering and segregating subjects who should be given special neuro-psychiatric examinations. The chairman of the subcommittee, who has been chiefly responsible for this work, will prepare an adequate account of the method and its results for publication in a suitable periodical.

10. Committee on "Propaganda Behind the German Lines." -This subcommittee, consisting of Scott and Angell, chairman, was appointed in December, 1917, by the Psychology Committee of the Research Council on motion of Dodge. This action followed urgent requests of Hall of the Psychology Committee that psychological assistance be rendered the War Department in connection with problems of military and civilian morale.

Prior arrangements of the War Department rendered it impossible for the subcommittee to accomplish anything in the direction originally indicated by the committee's discussion of needs, but subsequently members of the Psychology Committee were able to focus the attention of various officers of the General Staff on psychological aspects of the morale problem. 
The first noteworthy event in the control of military morale traceable indirectly to the influence of psychology in the army, was the preparation in March, I9I8, by Colonel E. L. Munson, of the Medical Corps, of a memorandum entitled "Need for a systematic plan for the psychological stimulation of troops in promoting fighting efficiency." This memorandum, which was prepared for the Surgeon General, was referred to the Division of Psychology, and after endorsement by that Division forwarded to the General Staff for consideration.

While Colonel Munson's memorandum was under advisement, representatives of the Psychology Committee were able to further the interests of psychological morale through numerous conferences with interested army officers and through the organizing at the suggestion of Dr. F. H. Keppel, Third Assistant Secretary of War, of two group conferences for the discussion of the morale problem and of ways of meeting the military need for enhanced morale.

These conferences were followed by favorable action with reference to Colonel Munson's recommendations, and there was ultimately established in the War Department the Morale Branch of the General Staff with Brigadier General E. L. Munson in charge.

Thus indirectly the Psychology Committee succeeded in stimulating military interest and in acquainting the War Department with morale needs to a degree which shortly led to most important official action.

In August, I918, the Psychology Committee voted to organize a subcommittee on Morale under the chairmanship of G. Stanley Hall. Unfortunately he was unable to assume this responsibility and the committee was never appointed.

A considerable number of men trained in military psychology were also trained at the Medical Department Training Camp, Fort Oglethorpe, Georgia, for practical work in military morale. Conspicuously important among the officers engaged in this work were Major William S. Foster, Captain Elliot P. Frost, and Lieutenant H. D. Fryer. At various times as many as twenty-five trained psychologists were en- 
gaged in this type of work. Still later several psychologists were placed on duty with the Morale Branch of the General Staff. Major Foster and Captain Frost rendered important service in this connection by organizing morale work in various camps. Major Foster also directed the study of military offences from the psychological standpoint, with a view to discovering their chief causes in order that appropriate steps might be taken by the War Department to eliminate or control them.

Morale is one of the subjects in which several members of the Psychology Committee, notably Hall and Dodge, were keenly interested from the onset of the military emergency. It is also a field of service in which the direct outcome of committee action is seemingly of trivial importance. Indirectly, however, the Committee through the interest aroused in War Department officials has achieved important service.

II. Committee on Acoustic Problems of Military Importance, consisting of R. M. Ogden, C. A. Ruckmich, Daniel Starch, Raymond Dodge, and C. E. Seashore, chairman, was not called upon to perform war work through committee organization. The chairman reports as follows:

"Immediately after the outbreak of the war, the chairman interviewed the officers in charge of the Training School for Listeners at New London and observed the types of acoustic instruments in use, the methods of using these instruments in locating submarines, and the method of selecting listeners for the training school. On the basis of these observations, a report was made to the Psychology Committee embodying suggestions for improving certain instruments then in use and for modifying methods and means of selecting listeners. The chairman later presented, through the Psychology Committee, a report upon preliminary experiments for the various methods that had been recommended for use in the selecting of listeners and submitted instruments which have been adapted for this service. One of these instruments was an audiometer designed in coöperation with Professor A. H. Ford. Two research assistants, Mr. H. M. Halverson and Mr. C. C. Bunch, were employed in the laboratory of the chairman for the dura- 
tion of the war, devoting their attention largely to these problems.

"Perhaps the most significant contribution is an instrument and a method of measuring acuity of hearing at all pitch levels very quickly and accurately. This is a problem on which Mr. Bunch was working in coöperation with the chairman, Dr. L. W. Dean, and Professor A. H. Ford. A report on this instrument was transmitted by the chairman of the Psychology Committee to the Surgeon General of the Army.

"Another problem undertaken in coöperation with Professor Ford, in charge of the school for radio-telegraphers, was the development of a series of tests to diagnose fitness for the radio service before the training of the cadet was undertaken. A report showing the operation of these tests was submitted to the Psychology Committee.

"The chairman has worked in close coöperation with Professor G. W. Stewart, who has presented a report to the Research Council on the selection of listeners for the detection of aëroplanes."

I2. Committee on Tests for Deception.-John F. Shepard, chairman, assisted by H. W. Crane and Mabel Goudge. This subcommittee was appointed to make inquiry concerning the reliability and practicability of certain procedures proposed by William M. Marston for the detection of deception.

By invitation of the chairman, Marston presented to the Psychology Committee a summary report on his methods and the results obtained in laboratory experiments. The purpose of his report appears in the initial sentence: "I respectfully submit that three psycho-physiological deception tests (association-reaction, breathing, and blood pressure) are of sufficient proven value to warrant practical application."

In response to request by Marston that the Committee arrange for adequate trial of his methods, either by the War Department or by the Department of Justice, he was asked to make application of his methods to a number of cases of actual crime, and to report the results to the Committee. This was promptly done, with positive results, and the Com- 
mittee thereupon appointed a subcommittee consisting of Angell and Yerkes to attempt to make provision for the tentative application of the Marston procedures by the Department of Military Intelligence.

Initial efforts to effect suitable arrangements through the War Department failed. Thereupon attention was directed to the Department of Justice, but early favorable response failed to lead to definite arrangements.

Finally Marston was commissioned in the Sanitary Corps for psychological service and while in training at Camp Greenleaf, Georgia, was able still further to supplement his earlier laboratory and court observations. The method involves the measurement of blood pressure during systematic cross examining. Ordinarily the Tycos sphygmometer is used and accurate record is kept of the subject's verbal responses so that variations in blood pressure as read at intervals or as recorded continuously may be studied in relation to the verbal responses.

The percentage of correct judgments, with reference to guilt or innocence, reported by Marston is extremely high. Thus in the case of the Greenleaf experiments, of thirty-five men tested, nineteen without knowledge of the examiner had chosen to steal, while sixteen were innocent and told the truth under cross examination. On the basis of blood pressure curves, Marston made thirty-four correct judgments, a percentage of 97.I. These findings are supported by those of previous carefully controlled laboratory experiments and of several instances of actual crime.

The subcommittee appointed to thoroughly investigate the Marston procedures has not been able to complete its task and no report is available for summary or publication.

The deception tests, because of their applicational history, did not command the confidence of all members of the Psychology Committee. To this fact may be attributed the conservative position taken, which involved first the desire for trial under the conditions of real life, as contrasted with the experimental laboratory setting, and finally, the recommendation of tentative trial by the Government. It is ex- 
tremely regrettable that such trial could not have been made, for the high percentage of correct judgments reported by Marston strongly suggests the probability of the practical serviceableness of blood pressure tests in connection with trial for military offence.

13. Committee on Adaptation of Psychological Instruction to Military Educational Needs.-Late in August, 19I8, the Chairman of the Psychology Committee received information from the Chairman of the Section on Relations with Educational Institutions that psychology would be listed as an "allied subject" of instruction in the Students' Army Training Corps. This information carried with it the suggestion that a training course in psychology suitable for use in the S. A. T. C. be prepared.

Following a conference on this subject, attended by members of the Committee on Education and Special Training of the War Department, members of the Psychology Committee of the National Research Council, and representatives of the American Psychological Association, the Chairman of the Psychology Committee appointed the following subcommittee to prepare appropriate methods for the Committee on Education and Special Training: J. W. Baird, E. K. Strong, Jr., L. M. Terman, E. L. Thorndike, G. M. Whipple, and Raymond Dodge, chairman.

This committee faced the task of arranging immediately for a training course in psychology which should conform to the general policies of the War Department committee.

Members of this subcommittee were promptly summoned to Washington for conference and it was decided to recommend the following three courses: I. The study of human action; II. Educational psychology; III. The psychology of reason. Each course was planned for a term of twelve weeks with three recitations and six hours of study per week.

The course entitled the "Study of human action" was carefully planned by the Committee in accordance with the experience and opinions concerning military needs set forth below.

"It is believed that the psychological principles which 
underlie established military practice as well as the principles on which the recent mental examinations and tests are based, should be brought together in a course in the study of human action for the S. A. T. C. and made available for all prospective officers including those who will spend only one quarter year in college. That is the idea of Course I.

"It is consequently recommended that the elementary course in 'the study of human action' be given in institutions which have the necessary equipment, omitting as far as possible all questions of a purely speculative or theoretical nature and concentrating on the relevant questions of applied psychology.

"While it is desired to leave each instructor the greatest freedom for personal initiative, it is recommended that reading assignments, formal reports, and recitation discussions be used rather than lectures, and that wherever practicable concrete military problems be used for illustration.

"It is further recommended that in contrast with the common plan of elementary courses in psychology, the emotions and the will be emphasized instead of the intellectual processes, and that the course be applied psychology rather than systematic.

"The subjects which are regarded as essential to such an elementary course in human action may be outlined under six sections.

I. The general characteristics of personal action and the conditions of effective reaction to new situations.

2. Individual differences and their military exploitation.

3. The learning process. General characteristics of habit formation. Plasticity. Fluctuation. Improvement and its limits. Fatigue.

4. Motivation and morale.

5. Principles of leadership.

6. The sources and critical estimate of information. The psychology of observation and report."

An arrangement was further made that materials for a fundamental course in human action as outlined above be prepared and made available for teachers in the Students' 
Army Training Corps as promptly as possible. The sections of this course were assigned as follows: Section I, Dodge; Section 2, Thorndike, Terman, and Strong; Section 3, Strong, Section 4, Hall; Section 5, Lindley; Section 6, Whipple. The editor of the Psychological Bulletin agreed to publish this text-book material. Sections I, 2, and 6 have already appeared. It is planned to complete the preparation of this material and, if the demand justifies it, to reprint the entire course as a volume.

The plans and materials for this course represent in a most interesting and valuable way the results of contact with psychological military problems and the attempt of psychologists to adapt themselves to a new and unexpected practical demand.

14. Psychological Service Rendered the Division of Military Intelligence.-Request for psychological assistance in the selection and training of scouts and observers was received both by the Division of Psychology and also by Whipple of the Psychology Committee from the Chief Intelligence Officer of an Army Division. In response to this request, advice and definite suggestions concerning methods were offered by Whipple, and the chairman of the Psychology Committee conferred with the intelligence officers of the War Department in order to formulate the chief psychological problems of the Division and arrange for their solution.

The Division of Military Intelligence later requested the assignment of a psychologist, in the military service, to prepare training tests to be used in the schools for intelligence officers. Major Watson and Captain Bentley were assigned to the task. They jointly prepared special tests which have been fully described in a chapter of the "Combat Intelligence Manual" of the War Department.

The materials of this chapter, including the tests, were selected and arranged for general instruction, special training, and as a basis for selection. The purpose of the several exercises presented is to test and develop visual, aural, and mental acuity.

The first few paragraphs of this chapter will serve to indi- 
cate both the scope and the purpose of the psychological labors undertaken by Watson and Bentley.

"An important function of a school of Military Intelligence is the training of the men to be generally alert and wide awake; to teach them to use their brains as well as their eyes and ears; and finally to show them that, even when they are doing their very best, they are liable to certain errors in observation, which arise partly through their own eagerness and expectation, and partly through slight defects in the sense organs themselves. The present simple course of training is designed to bring out these points and to give both training in the use of the eye and the ear, and in the noting and correct reporting of small details in observation. The exercises are all simple to give and they require neither extensive equipment nor a burdensome amount of work on the part of the group under instruction. The most important thing which can be said to the instructor is that he should thoroughly familiarize himself with such exercises before he attempts to instruct the group. The work can then be carried out in a dignified and impressive way. It is safe to predict that if the men are taken through all of the exercises in anything like a satisfactory way they will come out with a very much quickened ability to observe and a very much better estimate of their own abilities and weaknesses. They should be then in a much better frame of mind for receiving their more practical field instructions.

"The opening pages are devoted to some of the uses and peculiarities of vision. The intelligence scout or observer on duty at night depends to a great extent upon vision. It seems only fair to acquaint him with some of the more common functions of the eye.

"After this lecture has been given the instructor may proceed as rapidly as he can with Training Tests A, B, C, and D, which are designed both to test general alertness and to train the men to make close and detailed observations.

"Training Test $\mathrm{E}$ is designed to discover and to improve the men's ability to find their way and to keep their bearings in the dark. 
"Training Test $\mathrm{F}$ deals with hearing. It is designed to train the men to detect and localize faint sounds and to guard them against purely imaginary sounds."

The several tests referred to above deserve characterization:

Test for $\mathrm{A}$ is preliminary training in noting and naming various combinations of colored lights. It involves the use of a series of lamps in connection with a keyboard. The chief purposes of the test are to cultivate alertness, accuracy, and speed in reporting observations; to test and improve immediate memory and in general those functions which are most important in correctly observing and reporting the combinations of enemy rocket signals.

Test $\mathrm{B}$ is an adapted form of the army Picture Completion test. It is presented by means of lantern slides and its purpose is to increase the rapidity with which men notice details and detect obscure objects.

Test $\mathrm{C}$ is an adaptation of the army analogies or logical relations test. It also is presented by means of lantern slides and its chief purpose is to increase mental alertness. At the same time it is supposed to improve ability to think and to draw correct inferences.

Test $\mathrm{D}$ deals with estimates of numbers. Groups of men are presented by means of lantern slides and the subject is required to estimate quickly the number of individuals when position, attitude, and background are varied.

Test $\mathrm{E}$ has to do with orientation. It is at once a measure of the man's ability, and a means of training him to hold his directions and to find his way under varied conditions.

Test $F$ is planned as a measure of ability to detect and localize sounds (whistle and whisper). It is used also to train men to detect and localize sounds in the dark.

The services of Watson and Bentley were much appreciated by the Division, and the tests constitute an interesting contribution to the practical literature on the training of intelligence officers. It is probable also that the test materials will prove convenient and of value in various other types of situation. 
An additional psychological contribution to the training of intelligence officers was made by Carl Rahn, wholly independently of the Psychology Committee. He prepared a series of lectures and exercises for the men in the Intelligence Section at Camp Grant. Each of the lessons included (I) the statement of some important psychological principle; (2) an illustration to clinch the point; (3) a statement of applicability to scout and patrol; and (4) an exercise based upon the practical work of the detail. The officers in charge of this course at Camp Grant were of the opinion that the psychological work could be incorporated largely in the training course for men in the Intelligence Service.

The Rahn materials were transmitted to the Psychology Committee of the Research Council through James R. Angell and the Chairman of the Committee forwarded them to Watson, who at the time was in the service of the Division of Military Intelligence.

15. Psychological Assistance to the Chemical Warfare Service.-Dodge, Baird, and Dunlap assisted the Chemical Warfare Service by a special investigation of problems referred by that service and the preparation of reports and recommendations.

This work was initiated in response to an appeal from an officer of the Chemical Warfare Service for assistance with certain psychological problems connected with the tenancy of the gas mask. The chairman of the Psychology Committee referred the matter to the subcommittee on Visual Probalems. Dodge, of that committee, after preliminary analysis of the situation, conducted certain special investigations and submitted reports, the chief recommendations of which have been embodied in the latest form of mask. The following introductory statements indicate the important characteristics of the practical situation and the scope of Dodge's inquiry : 1

"Except for a few sporadic experiments, the mental and neuro-muscular effects of wearing a gas mask have not been investigated. We know neither the effects of the mask as a

${ }^{1}$ See also Dodge's account of the gas mask inquiry, p. I 20, above. 
whole nor the effects of its several parts. There are consequently no traditions to guide us either in the selection of the processes that are likely to be most affected, or in the order of the experiments. Even military traditions are relatively scant. There are no standard experiments that correspond to definite military tasks. There is no way of telling whether a given experimental disturbance is or is not of military consequence. Furthermore, there are no standard masks, fittings, or harness. There is no adequate analysis of the psychological and physiological problems that are involved.

"A serial investigation of the neural and mental effects of each part of the various masks now in use, or proposed for use, would be an investigation of some magnitude. It is doubtful if there are any available methods by which it could be satisfactorily completed. At present such an investigation is apparently particularly impracticable. The situation demands immediate results, not exhaustive programs. We lack available laboratory facilities and personnel as well as time and techniques.

"In view of these considerations, I proposed and have initiated an investigation consisting of two parts, calculated to give the most important information in the least possible time.

"Part I. A preliminary experimental exploration of the effects of as many different types of mask as may be called for, using a single observer, techniques that have proved themselves useful in previous investigations of neuro-muscular condition, and sufficient repetition to avoid gross chance errors.

"Such an exploration should discover: (I) the direction of any gross disturbances; (2) the kinds of measurement and procedure that are likely to prove useful in squad experiments; and (3) more or less probable indications of especially desirable and undesirable features of the various masks.

"Part 2. From the exploration, it should be possible with military assistance to devise definitive military group tests of the relative satisfactoriness of available masks." 
In addition to noting the effects of the mask on various forms of reaction, Dodge made special study of head air space, characteristics of eye pieces, ventilation of the face, adaptation and tolerance, recovery of capacity after removal of the mask, side inspirational tubes, the relation between neuromuscular depression and the ability to endure the mask, regulation of the pressure of the head-gear, gas mask sizes, the most economical development of tolerance to gas mask tenancy of long duration, the relative military value of different mask types for long tenancy, and the effects of resistance on tenancy and the performance of military tasks.

Major Knight Dunlap was assigned to duty with the Chemical Warfare Service to continue and extend the investigations on tenancy of the gas mask initiated by Dodge. His attention was confired in the main to measurement of the visual fields of different types of gas masks by an original method which dispensed with the head-gears and also to the development of a pneumatic scheme for measuring relative pressures on the head at different parts of the mask. This scheme, perfected technically by the Goodrich Company, was subsequently applied to the comparison of different types of mask. It served to show that the mask, even when so adapted as to be leak proof, exerted less pressure, and also showed a more even distribution of pressure, than the other masks previously used, although the latter were not free from leaks even with the higher pressures employed.

Just prior to the signing of the armistice, Dunlap had perfected a procedure for determining the effects of different types of masks on the efficiency of the wearer. He proposes to continue this inquiry in his own laboratory in view of the practical value of a perfected mask in certain civilian occupations.

The Chemical Warfare Service further sought the services of the Psychology Committee in connection with the problem of camouflaging odors, and as a result of a conference with Captain Carleton, Vice-chairman Baird of the Psychology Committee prepared a report in which he summarized pertinent physiological and psychological literature on the 
classification of odors, relationship of odors, and the relation between odor and chemical composition of substance.

Despite the fact that complete cancellation seemingly does not occur, Baird concludes that the intensity of an odor is so far reduced by compensation as to effect valuable camouflage. On the basis of this practical inference, he recommends the use of the methods of fatigue and of cancellation in camouflaging.

The work done by Dodge, Baird, and Dunlap demonstrated the existence of important psychological and physiological problems within the Chemical Warfare Service and the ability of psychologists to speedily achieve practical solution of such problems in the interests of military efficiency.

16. Psychological Service to the Committee on Education and Special Training of the War Department.-Conferences for considering suitable methods for selecting, classifying, and placing men for instruction in Students' Army Training Corps institutions were attended by representatives of the Psychology Committee, the Division of Psychology, Committee on Education and Special Training, and the Committee on Classification of Personnel. Thorndike, Terman, and Yerkes acting jointly, decided to suggest to the Committee on Education and Special Training that the army mental tests be adapted to meet the special requirements of the Students' Army Training Corps.

In a memorandum addressed to Charles R. Mann of the Committee on Education and Special Training, it was recommended that L. M. Terman be designated to adapt methods and to prepare plans for their administration in connection with the S. A. T. C. It was further suggested that the army group examination for literates (the Alpha examination) be administered in adapted form by the Committee on Education and Special Training with the advisory assistance of the Division of Psychology, Medical Department of the Army.

This recommendation was favorably received by the educational committee, and Terman was promptly assigned to duty with it. He immediately prepared for A. C. Tinal, Director of educational measurements for the Committee, 
an adaptation of the Alpha examination in which, aside from differences in directions, the principal modification was the omission of the reading by the examiner of detailed instructions for the several tests. This lessened the time available for each test by requiring the subject to read the directions for himself during the period allowed in the army form of the examination for actual performance.

Having completed the adaptation of procedure, Terman presented army mental test methods to members of the educational committee and also discussed their practical results. This demonstration and exposition led to the decision that the Alpha examination should be universally used for the examination of the members of the Students' Army Training Corps.

It had been definitely planned and anticipated that the introduction of the methods would be directed by a few competent individuals employed by the Committee on Education, and that the actual conduct of the tests would be left to a member of each institution designated by the President. Everything was in readiness for the administration of tests to the first group of students in the Students' Army Training Corps when the signing of the armistice interrupted the work of the Committee.

Numerous institutions had meantime directed requests to nearby army training camps that their examining staffs representing the Division of Psychology, Surgeon General's Office, make psychological examination of their men. This was impossible because the Division of Psychology had delegated responsibility for the conduct of mental tests to the Committee on Education and Special Training.

After the signing of the armistice, because of the widespread demand for further information concerning army mental tests and opportunity to use them in connection with the Students' Army 'Training Corps, the Committee on Education arranged through the Division of Psychology of the Surgeon General's Office, to supply copies of the Alpha examination blank to such institutions as desired them. About one hundred institutions signified their desire to use the examination. 
Except for numerous delays, the Alpha examination would have been administered to all members of the Students' Army Training Corps during the initial quarter, and thereafter either to applicants or to students already enrolled, for assistance in connection with classification and instruction.

The work of Terman would have been of increasing practical value had the Students' Army Training Corps continued in existence; but despite the failure to bring the tests into actual use, it is clear that important service was rendered by acquainting the educational committee, many additional army officers, and members of upwards of five hundred educational institutions, with this method of mental classification.

I7. Miscellaneous Work for Various Military and Civilian Agencies.-L. L. Thurstone of the Carnegie Institute of Technology carried on an important investigation in the selection and training of telegraphers. At the outset two facts were discovered which proved of far-reaching significance. First, analysis of the progress of drafted men in Class ra who were preparing to enter the service with some knowledge of telegraphy showed that many well-educated men did not succeed in learning telegraphy as well as might have been expected from their general intelligence and education. Second, the converse also proved true, that some men of very modest education and general ability found it easy to learn the telegraphic code. From these two facts was drawn the initial assumption that ability to learn the telegraphic code is a special ability. A series of tests were devised to predict the presence or absence of this ability, in order that future selections of telegraphers might be to the best advantage of the service and the men. A report on these tests will be published in the Journal of Applied Psychology.

Herbert S. Langfeld, during the summer of I9I8, made an official trip to France to observe from the point of view of a psychologist the personnel of the Y. M. C. A. His excellent opportunities to observe American soldiers in rest and leave areas, in training schools, and in trenches, supplied materials for a valuable report which, on his return to America, was transmitted to the Psychology Committee of the National Research Council. 
The principal subjects of this report are: psychological problems of morale, the aviation service, reconstruction, shell-shock, and camouflage. In each of these subjects Langfeld made interesting and important observations upon which he bases suggestions for practical service. Thus, for example, in connection with camouflage work, he states that one of the most interesting problems, with important psychological aspects is the camouflage of motion, especially in relation to aëroplanes. He further reports that the assistance of psychologists was greatly desired by the officers engaged in camouflage.

Had the war continued, Langfeld's observation of conditions and his suggestions would undoubtedly have led to important developments of psychological service overseas.

In the summer of I9I 8 an American psychologist who had observed conditions in Paris reported to the Psychology Committee that assistance might, in his judgment, be rendered the Y. M. C. A. in selecting suitable personnel for service overseas. The facts gathered by this observer were transmitted to the Office of the Secretary of War and as a result of careful consideration of the matter, the Y. M. C. A., in October, 1918, introduced the army mental tests (Group Examination Alpha) in all of its special training schools as a supplementary means of eliminating undesirable applicants. The Medical Department of the Army coöperated with these training schools by supplying the necessary materials for examinations and such standards of judgment and other information as might prove of assistance to the examining officers.

This work was instituted at such a late date that results of statistical value could not be obtained. Psychological examiners in the army were able, however, to render assistance to the Y. M. C. A. in training camps and also in a few of the special Y. M. C. A. training schools. Arrangements had been made by the New York headquarters of the Y. M. C. A. for the conduct of psychological examination of candidates for overseas service by Robert S. Woodworth of Columbia University. Approximately five hundred examinations had been made before the armistice cut short this work. 
Of special interest is the fact that the executive officers of this organization, after trying other methods of selection to improve the Y. M. C. A. personnel, decided that the army procedure for measuring mental alertness should be introduced.

IV. Future Relations of Psychology to the National Research Council.

The eager and effective coöperation of psychologists in professional war work has enabled the Psychology Committee to win the confidence and the hearty support of the several scientific groups which together constitute the Research Council. Largely because of the way in which it responded to the practical demands and the opportunities of the military emergency, psychology today occupies a place among the natural sciences which is newly achieved, eminently desirable, and highly gratifying to the profession. An immediate result of this improved status is the desire of the Executive Board of the Research Council to have psychology adequately represented in the permanent national organization.

A conference of psychologists called for the discussion of the relations of psychology to the organization of the Research Council, unanimously approved the inclusion of psychology in the national organization and formulated the following as a tentative statement of the functions of the psychological section of the Council:

"I. Service, in an advisory capacity, to the Government and its various agencies in connection, for example, with psychological problems of education, immigration, civil service, military organization, public health, and labor.

2. The stimulation and facilitation, coördination, conduct of psychological research.

" 3 . The furtherance of the international relations of psychology and psychologists in the interests alike of research and effective instruction.

"4. The study and improvement of the status of the relations of psychology as science and as technology.

" 5. Concern with such generally important matters of psychological personnel as the qualifications of individuals for research tasks and measures for maintaining and improving the quality of the professional personnel." 
It is proposed to associate psychology with anthropology in a Division whose chairman and vice-chairman shall be chosen alternately from the two sciences, a chairman from anthropology serving with a psychologist as vice-chairman and vice versa.

If psychology is to meet successfully the now rapidly increasing practical demands by which it is challenged, it must organize for coöperative endeavor in a way not thought of prior to the war. On the one hand is the imperative need of highly developed and specialized methods; on the other, the - need for largely increased and adequately trained personnel. The war activities of the Psychology Committee have revealed or created opportunities whose scientific and practical significance cannot be estimated. Two years ago mental engineering was the dream of a few visionaries. Today it is a branch of technology, which, although created by the war, is evidently to be perpetuated and fostered by education and industry.

Psychology needs therefore as never before in its history intimate association with the more exact natural sciences, as well as with the biological sciences which are more nearly related to it. The support and coöperation of other scientists and especially their intelligent interest, are indispensable.

For the speedy and sound development of psychology as science and as technology, the National Research Council should prove the most important of agencies. It is earnestly to be desired that the psychologists of the country may unite in their support of this national organization for the promotion of scientific research, its practical applications, and the profitable relations of sciences and of scientists. 




\section{UNIVERSITY OF CALIFORNIA LIBRARY}

Los Angeles

This book is DUE on the last date stamped below.

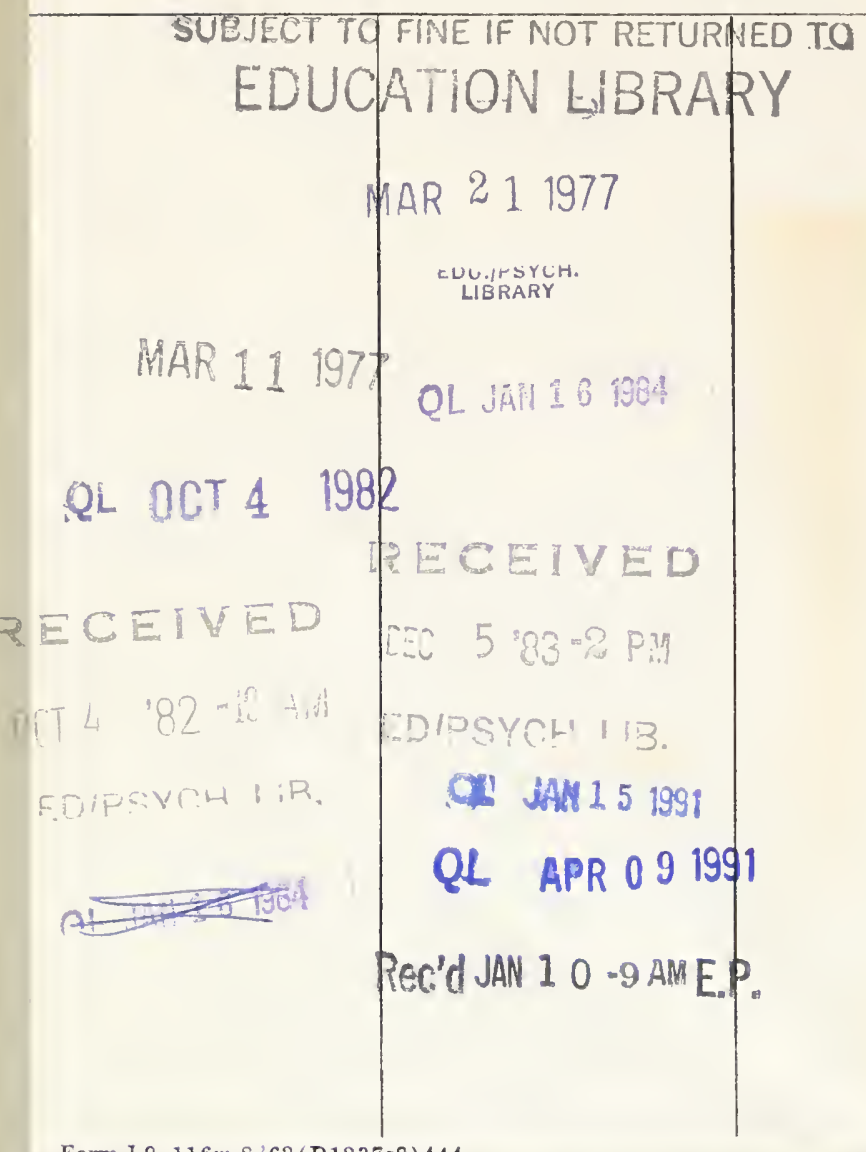


Gaylord Bros.

Makers

Stockton, Calif.

UCLA-ED/PSYC

BF $131 \mathrm{~N} 21 r$
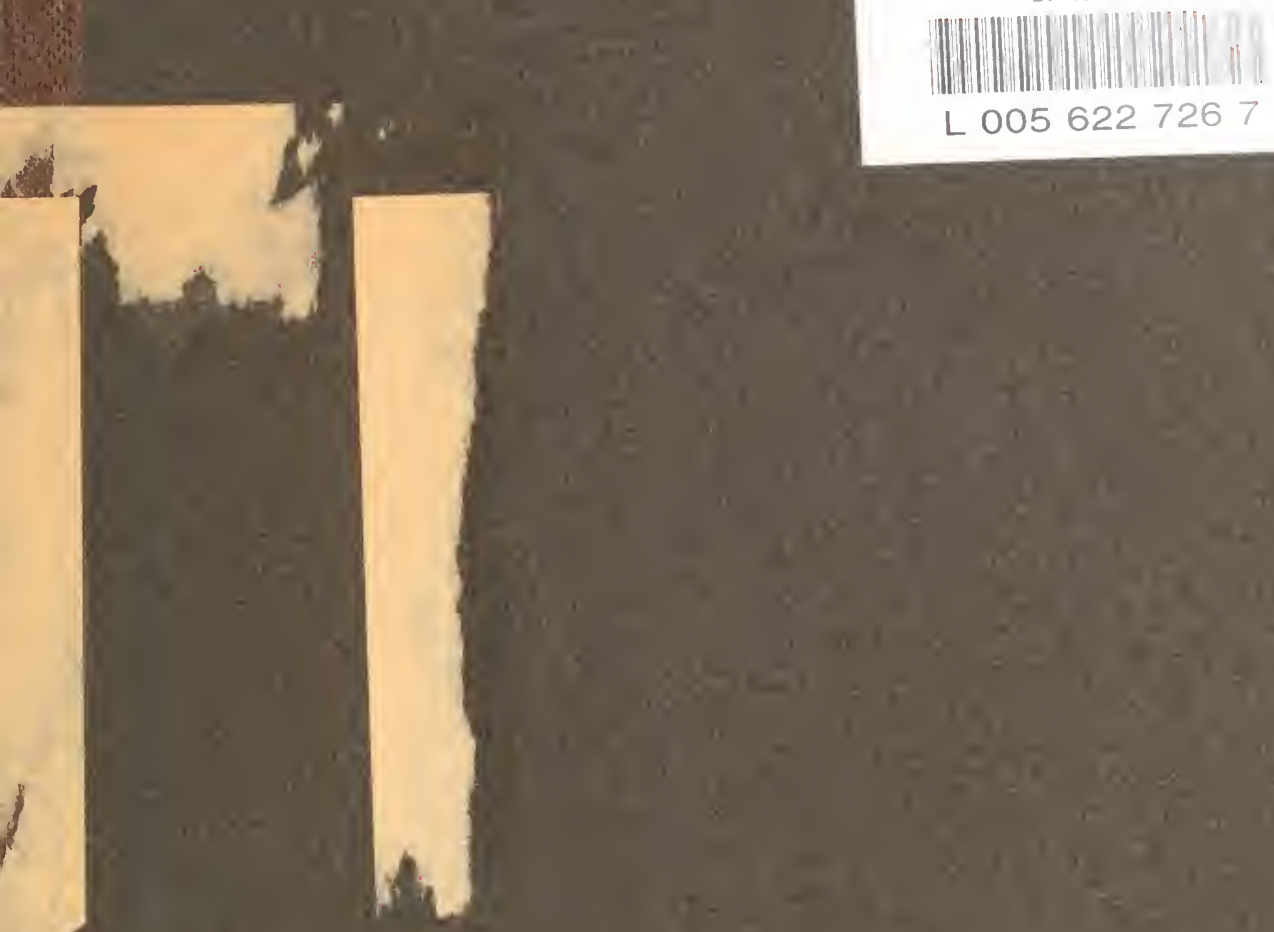
